\title{
Gaseous phase above Ru-O system: a thermodynamic data assessment
}

\author{
Ioana Nuta ${ }^{*}$, Christian Chatillon, Fatima-Zahra Roki, Evelyne Fischer \\ Univ. Grenoble Alpes, CNRS, Grenoble INP, SIMaP, F-38000 Grenoble, France \\ 1130 rue de la piscine BP 7538402 Saint Martin d'Hères \\ * Corresponding author: Ioana Nuta, Tel.: +33 476826511 \\ E-mail address: ioana.nuta@grenoble-inp.fr
}

\begin{abstract}
The present study is a critical assessment of thermochemical data for gaseous ruthenium oxides based on available experimental data. A full critical analysis and a reinterpretation of data are presented with a proposition for new accurate standard formation enthalpies values: $\Delta_{\mathrm{f}} \mathrm{H}^{\circ}{ }_{298}\left(\mathrm{RuO}_{4}, \mathrm{~g}\right)=-197.6 \pm 5.5 \mathrm{~kJ} \mathrm{~mol}^{-1}, \Delta_{\mathrm{f}} \mathrm{H}^{\circ}{ }_{298}\left(\mathrm{RuO}_{3}, \mathrm{~g}\right)=-53.0 \pm 10 \mathrm{~kJ} \mathrm{~mol}^{-1}$, $\Delta_{\mathrm{f}} \mathrm{H}^{\circ}{ }_{298}\left(\mathrm{RuO}_{2}, \mathrm{~g},\right)=158 \pm 20 \mathrm{~kJ} \mathrm{~mol}^{-1}$ and $\Delta_{\mathrm{f}} \mathrm{H}^{\circ}{ }_{298}(\mathrm{RuO}, \mathrm{g})=301 \pm 28 \mathrm{~kJ} \mathrm{~mol}^{-1}$.
\end{abstract}

Keywords: Thermodynamic data, $\mathrm{Ru}-\mathrm{O}$, gas phase, Entropy, Formation enthalpy, $\mathrm{RuO}_{4}(\mathrm{~g})$, $\mathrm{RuO}_{3}(\mathrm{~g}), \mathrm{RuO}_{2}(\mathrm{~g}), \mathrm{RuO}(\mathrm{g})$, critical assessment

\section{Introduction}

Knowledge of the gas phase thermodynamic properties of the $\mathrm{Ru}-\mathrm{O}$ binary system is important for at least three main applications: - (i) the corrosion behavior of Ru electrodes or $\mathrm{RuO}_{2}$ (s) catalytic coatings - (ii) the evaporation of some Ru species above $373 \mathrm{~K}$ during nitric acid treatment of the Ru containing burned nuclear fuels that have been supposed containing mainly $\mathrm{RuO}_{4}(\mathrm{~g})$ or related molecules, or - (iii) in severe nuclear accident releases.

In the $\mathrm{Ru}-\mathrm{O}_{2}$ system, there exists two condensed oxides:

(i) $\mathrm{RuO}_{2}(\mathrm{~s})$ the thermodynamic properties of which have been recently compiled and assessed by Gossé et al [1] and Chatillon et al [2];

(ii) $\mathrm{RuO}_{4}(\mathrm{~s})$ that melts at room temperature and vaporizes with significant total vapor pressure at low temperature as determined by Nikol'ski (1964) [3].

The gas phase composition of the $\mathrm{Ru}-\mathrm{O}$ system has been studied only above the $\mathrm{Ru}-\mathrm{RuO}_{2}$ range where the molecules of $\mathrm{RuO}_{4}(\mathrm{~g}), \mathrm{RuO}_{3}(\mathrm{~g}), \mathrm{RuO}_{2}(\mathrm{~g})$ and $\mathrm{RuO}(\mathrm{g})$ are identified by independent spectroscopic methods and by quantum chemistry and their structure is given. In the last compilation made in 1990 by Cordfunke and Konings [4] the free energy functions have been only estimated because a lack of experimental values concerning the structural data of the molecules.

The present work improve this first selection of thermodynamic properties by taking into account more complete experimental data sets. In the first step of this study, a literature review of the structural properties of the gaseous molecules of $\mathrm{Ru}-\mathrm{O}$ system and their thermodynamic functions is made. Then, starting with these selected values, new third law calculations are performed to propose more accurate values than those proposed in the last compilation [4] . 


\subsection{Assessment of structures of $\operatorname{RuO}_{n}(n=1$ to 4$)$ gaseous molecules}

First step in the thermodynamic knowledge of gaseous molecules is the determination of the structural properties of the molecules: their geometry (i.e. interatomic distances and bond angles), vibration frequencies, rotational constants as well as their electronic states.

Interatomic Ru-O distances in the gaseous molecules as well as methods of measurement and / or calculations come from Hameka et al.[5], Siegbahn [6], Miradji et al [7], Zhou et al [8], Krauss et Stevens [9], Schäfer et al. [10] and Scullman and Thelin [12]. Distances in the two varieties of $\mathrm{RuO}_{4}(\mathrm{~s})$ solid crystal published by Pley and Wickleder [11] are considered (see Table 1 in Appendix I).

\subsection{1 $\mathrm{RuO}_{4}(\mathrm{~g})$ molecule}

Molecular parameters of $\mathrm{RuO}_{4}(\mathrm{~g})$ as proposed in literature and used throughout this work are presented in Table I-2 in Appendix I. The selected structure is a tetrahedral molecular structure, strictly regular $\left(\mathrm{T}_{d}\right)$, in agreement with that proposed by Greene et al [13]. Pley and Wickleder [11] by X-ray diffraction of $\mathrm{RuO}_{4}(\mathrm{~s})$ crystal showed that the crystal is formed of tetrahedral entities with Ru-O distances ranging from $1.695 \AA$ (cubic structure) to $1.701 \AA$ (monoclinic structure).

Normally, the gaseous molecule has a more relaxed structure because there are no nearest neighbors, thus, $\mathrm{RuO}_{4}(\mathrm{~g})$ would be similar to the most relaxed solid entity, i.e. the monoclinic. The geometry of the $\mathrm{RuO}_{4}(\mathrm{~g})$ molecule was analyzed by Braune and Stute [14] by electron diffraction from molecular beam on the basis of a regular tetrahedron structure and then more recently by Schäfer et al. [10] with an improved technique. In the present study, the retained interatomic distance value for $\mathrm{Ru}-\mathrm{O}$ in $\mathrm{RuO}_{4}(\mathrm{~g})$ is set as proposed by Schäfer et al [10] (i.e. $\mathrm{r}$ Ru-O with $1.7058 \pm 0.003 \AA$ ) because it is considered as slightly relaxed $(0.3 \%)$ as for the condensed phase when a monoclinic crystal structure is considered. Quantum calculations (see Table I-2 in Appendix I) give smaller values resulting in higher vibration frequencies (mainly verified with the normal symmetric vibration $v_{1}$ ). Several authors determined the $v_{3}$ (anti-symmetric) vibration frequency using IR spectroscopy (Table I-2 in Appendix I): experimental measurements are in agreement, around $920 \mathrm{~cm}^{-1}$, meanwhile ab-initio calculations gave higher values ranging from 923 to $974 \mathrm{~cm}^{-1}$. Generally, frequencies obtained by quantum or ab-initio calculations are higher than those measured because the calculated equilibrium interatomic distance is smaller than the measured one and these are related to a slightly greater force constant. After analysis of the band contours in spectroscopy, the complete set of experimental vibration frequencies proposed by McDowell et al [15] is retained in this work with the only vibration frequencies resulting from Ar matrix isolation. Indeed, those measured in the presence of $\mathrm{Ne}$ are discarded because they might be influenced by Van Der Vaals interactions in the case of this rare gas with higher molar mass. The ab-initio frequency set calculated by Hameka et al [5] and Miradji et al [7] confirms the present experimental selection while being slightly higher in relation with an interatomic $\mathrm{Ru}-$ $O$ distance calculated shorter than from our selected experimental values. The selected ground electronic state is the one calculated by Miradji et al [7] ${ }^{1} \mathrm{~A}_{1}$ with a triplet state at an electronic level $14210 \mathrm{~cm}^{-1}(1.76 \mathrm{eV})$.

\subsection{2 $\mathrm{RuO}_{3}(\mathrm{~g})$ molecule}

Molecular parameters of $\mathrm{RuO}_{3}(\mathrm{~g})$ as proposed in literature and used throughout this work are presented in Table I-3 in Appendix I. The structure of the $\mathrm{RuO}_{3}(\mathrm{~g})$ molecule is planar type one 
with $120^{\circ}$ angle $\left(D_{3 h}\right)$. The only measured vibration frequency $v_{3}$ by Kay et al [16] is rather confirmed by ab-initio calculations of Miradji et al [7] with some shift. The comparison of $\mathrm{Ru}-\mathrm{O}$ interatomic distances between $\mathrm{RuO}_{4}(\mathrm{~g})$ and $\mathrm{RuO}_{3}(\mathrm{~g})$ (see Table I-3 in Appendix I) obtained by various quantum chemistry calculations shows that there is no (or very little) hybridization of the released electrons with those in other orbitals. Thus, the $\mathrm{RuO}_{3}(\mathrm{~g})$ molecule keeps the same interatomic distance as in the saturated $\mathrm{RuO}_{4}(\mathrm{~g})$ molecule. Consequently, in this study, the experimental interatomic distance proposed for $\mathrm{RuO}_{4}(\mathrm{~g})$ was retained for the $\mathrm{RuO}_{3}(\mathrm{~g})$ molecule and farther for $\mathrm{RuO}_{2}(\mathrm{~g})$. The ground electronic state of $\mathrm{RuO}_{3}(\mathrm{~g})$ selected is that calculated by Miradji et al [7] ${ }^{1} \mathrm{~A}_{1}$ with a triplet state at an electronic level $5183 \mathrm{~cm}^{-1}(0.64 \mathrm{eV})$.

\subsubsection{The $\mathrm{RuO}_{2}(\mathrm{~g})$ molécule}

Molecular parameters of $\mathrm{RuO}_{2}(\mathrm{~g})$ as proposed in literature and used throughout this work are presented in Table I-4 in Appendix I. Two experiments of IR spectroscopy ([16], ,[8]) are in relative agreement and propose a $\mathrm{C}_{2 \mathrm{v}}$ type structure with a $150 \pm 2^{\circ}$ angle. Vibration frequencies (symmetric and anti-symmetric in the axis of the bonds) that was experimentally measured are in relative agreement, while ab-initio calculations give some higher symmetrical frequencies. These higher values reflect the downward trend in frequency measured when molecules are trapped in Ar or Ne matrix. The general trend shows small difference between the two experimental symmetrical frequencies $v_{1}$ and anti-symmetric $v_{3}$ - particularly determined by Kay et al [16] - in agreement with ab-initio work of Miradji and al [7]. Given this agreement and because the bending frequency $v_{2}$ was not experimentally determined, the present study retains the value of $v_{2}$ calculated by Miradji et al [7]. To be consistent between frequencies and interatomic distance, the value proposed by Miradji et al [7] is proportionally adjusted with the average ratio deduced from frequencies $v_{1}$ and $v_{3}$. For the electronic state, the basic one is a singlet sigma ${ }^{1} \mathrm{~A}_{1}$ type and, as proposed by two quantum calculations, there exists a triplet state at $334 \mathrm{~cm}^{-1}$ level. Since no other available experimental information exists, this study retains these values for the electronic states.

\subsubsection{The RuO(g) molecule}

Molecular parameters of $\mathrm{RuO}(\mathrm{g})$ as proposed in literature and used throughout this work are presented in Table I-5 in Appendix I. This study retains the values from atomic emission spectroscopy obtained by Scullman and Thelin [12], who already corrected the data of Raziunas et al [20]. Ab-initio calculations of Miradji et al [7], more refined than other previous calculations give interatomic distance and vibration frequency close to experimental values. The calculated $\mathrm{Ru}-\mathrm{O}$ distance in the molecule $\mathrm{RuO}(\mathrm{g})$ shows a weakened bond due to the presence of non-bonding orbitals, which probably play a "repulsive" role (anti-bonding). This bond length is consistent with spectroscopic results (Table I-1 and Table I-5 in Appendix I). The ground electronic state selected takes into account the first level observed by spectroscopy. 


\subsection{Compilation of published gaseous molecules formation enthalpies}

Thermodynamic studies of the Ru-O system gas phase stability have been carried out: - (i) using transpiration or transport methods mainly for the study of $\mathrm{RuO}_{4}(\mathrm{~g})$ and $\mathrm{RuO}_{3}(\mathrm{~g})$ molecules, - (ii) using mass spectrometry for the study of $\mathrm{RuO}_{2}(\mathrm{~g})$ and $\mathrm{RuO}(\mathrm{g})$ molecules.

\subsubsection{Works using transpiration methods}

Schäfer et al [24-26] carried out three kinds of experiments:

- Heating a Ru filament in a controlled oxidizing atmosphere (the so-called "incandescent filament technique") with evaluation of the filament mass loss by weighing before and after heating

- Continuous weighting with a thermo-balance of Ru samples subjected to oxidation and $\mathrm{H}_{2}$ reduction cycles to evaluate the volatility of $\mathrm{Ru}$ oxides in relation to the $\mathrm{Ru}$ loss of the initial sample

- Total pressure measurement by a static method i.e. manometry at cold point (room temperature at walls).

In the incandescent filament technique, Ru loss of the filament is performed at two oxygen pressures for the same temperature (pyrometric monitoring of filament surface). Some experiments are carried out in sealed glass ampoules followed by a heat treatment. Ru mass losses allows the authors to determine the main vaporization reactions from the different proportions of $\mathrm{Ru}$ losses related to the $\mathrm{O}_{2}(\mathrm{~g})$ pressure according to the following reactions,

$$
\begin{aligned}
& \mathrm{Ru}(\mathrm{s})+3 / 2 \mathrm{O}_{2}(\mathrm{~g})=\mathrm{RuO}_{3}(\mathrm{~g}) \\
& \mathrm{RuO}_{2}(\mathrm{~s})+1 / 2 \mathrm{O}_{2}(\mathrm{~g})=\mathrm{RuO}_{3}(\mathrm{~g}) \\
& \mathrm{RuO}_{2}(\mathrm{~s})+\mathrm{O}_{2}(\mathrm{~g})=\mathrm{RuO}_{4}(\mathrm{~g})
\end{aligned}
$$

At low temperature, the proportionality observed between the mass losses and the pressure $\mathrm{p}\left(\mathrm{O}_{2}\right)$ (reaction (3)) indicates that $\mathrm{RuO}_{4}(\mathrm{~g})$ molecule is in equilibrium with $\mathrm{RuO}_{2}(\mathrm{~s})$ and that this molecule is predominant in the gas phase. Conversely, at high temperature $\mathrm{RuO}_{3}(\mathrm{~g})$ predominates since the mass loss is proportional to pressure $\mathrm{p}\left(\mathrm{O}_{2}\right)^{3 / 2}$ on $\mathrm{Ru}(\mathrm{s})$ and to pressure $\mathrm{p}\left(\mathrm{O}_{2}\right)^{1 / 2}$ on $\mathrm{RuO}_{2}(\mathrm{~s})$.

Schäfer et al [26] have published two tables (on pages 50 and 51) with the partial pressures of $\mathrm{RuO}_{4}(\mathrm{~g})$ and $\mathrm{RuO}_{3}(\mathrm{~g})$ and the equilibrium constants of reactions (2) and (3). Schäfer et al [26] selected two measurements at two temperatures $-1069 \mathrm{~K}$ for $\mathrm{RuO}_{4}(\mathrm{~g})-1477 \mathrm{~K}$ for $\mathrm{RuO}_{3}(\mathrm{~g})$ - to deduce reaction (2) and (3) enthalpies. They estimated entropies of $\mathrm{RuO}_{2}(\mathrm{~s})$ and $\mathrm{Cp}$ of $\mathrm{RuO}_{3}(\mathrm{~g})$ and $\mathrm{RuO}_{4}(\mathrm{~g})$ gaseous molecules to deduce enthalpies of reactions (2) and (3) at $298 \mathrm{~K}$, then enthalpies of formation.

Bell and Tagami [27] confirm, by varying the oxygen content at different temperatures in a transpiration device, that the vapor is mainly composed of $\mathrm{RuO}_{3}(\mathrm{~g})$ and $\mathrm{RuO}_{4}(\mathrm{~g})$. Then, quantitative experiments are performed by method of transpiration under $\mathrm{O}_{2}$ flow at one 
atmosphere with a $\mathrm{RuO}_{2}$ (s) sample doped by a radiotracer. The mass transport of total $\mathrm{Ru}$ is performed by radiometric analysis of deposit at the output. It is assumed that the total transport is proportional to the sum $\mathrm{p}\left(\mathrm{RuO}_{3}\right)+\mathrm{p}\left(\mathrm{RuO}_{4}\right)$ according to reactions (2) and (3). The authors [27] estimated the proportions of $\mathrm{RuO}_{3}(\mathrm{~g})$ and $\mathrm{RuO}_{4}(\mathrm{~g})$ in the vapor from these mass losses according to relation,

$$
p_{\mathrm{RuO}_{3}}+p_{\mathrm{RuO}_{4}}=A e^{C / T}+B e^{D / T}
$$

in the temperature range $1075-1776 \mathrm{~K}$ and by an iterative method they determine all constants. These four constants are related to the enthalpies and entropies of reactions (2) and (3) and their fit is a general treatment based on 2nd law of thermodynamics that determines the enthalpy and entropy values of the two reactions at mean temperature.

Penman and Hammer [28] performed a transpiration experiment with an oxygen carrier gas on a sample of $\mathrm{RuO}_{2}(\mathrm{~s})$. The pressure of the oxygen, which is fed counter-currently in the furnace shell to the evaporation chamber, is determined by means of a mercury manometer, while the vapors of the gaseous oxides of Ru escape through a capillary tube and then condense in a glass wool. Deposits are then dissolved to analyze the transported amount of Ru by scintillation. Different capillary tube diameters are used to certify that the extracted gas is saturated within a flow range of a factor 10. However, the authors [28] do not give any indication on the differences observed nor on the determination of a plateau as a function of the carrier gas flow rate as is usually done in the transpiration method: constant determined pressure values correspond at least to part of the usual plateau. Based on the experiments of Schäfer et al [24-26] and a constant temperature test with different oxygen pressures, the authors proposed a vapor mainly composed of $\mathrm{RuO}_{4}(\mathrm{~g})$ in their low temperature range i.e. 726 - $996 \mathrm{~K}$.

\subsubsection{Works using mass spectrometry}

Tagirov et al [29] vaporized $\mathrm{RuO}_{2}(\mathrm{~s})$ in quartz effusion cells between 980 and $1190 \mathrm{~K}$ and measure the $\mathrm{O}_{2}$ pressure by mass spectrometry without detecting any other $\mathrm{Ru}$-based gaseous species, probably due to insufficient mass spectrometry sensitivity. Indeed, according to Schäfer et al [26] and Bell and Tagami [27] $\mathrm{RuO}_{3}(\mathrm{~g})$ and $\mathrm{RuO}_{4}(\mathrm{~g})$ would have a proportion $\approx 10^{-3}$ to $10^{-4}$ relatively to oxygen pressure, a proportion that can be measured in the usual detection range of mass spectrometry using effusion cells.

To circumvent the sensitivity requirements of the mass spectrometer and promote the dissociation of complex gaseous oxides, Norman et al [23] carried out a mass spectrometric study using an effusion cell equipped with an $\mathrm{O}_{2}$ gas flow inlet to stabilize the oxygen potential by compensating for the preferential oxygen lost by effusion. For low temperature studies $(<1500 \mathrm{~K})$, the sample is pure $\mathrm{Ru}$ placed in a quartz cell, and for higher temperatures the authors [23] use an alumina cell. The $\mathrm{O}_{2}(\mathrm{~g})$ pressure in the cell has been set at about $10^{-4}$ bar (this $10^{-4}$ bar, we assume, must be the usual upper pressure limit for the effusion method) according to the authors' [23] estimates and they can vary it by a factor 10 (probably below $10^{-4}$ bar). The authors [23] analyzed the slope of the measured ionic intensities of $\mathrm{RuO}_{3}{ }^{+}, \mathrm{RuO}_{2}{ }^{+}$and $\mathrm{RuO}^{+}$at low temperature as a function of the variation in the oxygen potential $\mathrm{p}\left(\mathrm{O}_{2}\right) \approx$ intensity $\left(\mathrm{O}_{2}{ }^{+}\right)$and they observed a break indicating the transformation of the sample from $\mathrm{Ru}(\mathrm{s})$ to $\mathrm{RuO}_{2}(\mathrm{~s})$. In the low temperature range, 
they study the following reactions that produce $\mathrm{RuO}_{3}(\mathrm{~g})$ which is the main detected gaseous species,

$$
\begin{gathered}
\mathrm{Ru}(\mathrm{s})+3 / 2 \mathrm{O}_{2}(\mathrm{~g})=\mathrm{RuO}_{3}(\mathrm{~g})(1295-1538 \mathrm{~K}) \\
K_{p}(1)=\frac{\mathrm{p}_{R u O_{3}}}{a_{R u} \cdot \mathrm{p}_{O_{2}}^{3 / 2}} \approx \frac{I_{R u O_{3}^{+}} T}{1 \cdot\left(I_{O_{2}^{+}} \cdot T\right)^{\frac{3}{2}}} \approx I_{R u O_{3}^{+}} \cdot T^{-1 / 2} \\
\mathrm{RuO}_{2}(\mathrm{~s})+1 / 2 \mathrm{O}_{2}(\mathrm{~g})=\mathrm{RuO}_{3}(\mathrm{~g})(1147-1228 \mathrm{~K}) \\
K_{p}(2)=\frac{\mathrm{p}_{R u O_{3}}}{a_{R u O_{2}} \cdot \mathrm{p}_{O_{2}}^{1 / 2}} \approx \frac{I_{R u O_{3}^{+}}}{1 \cdot\left(I_{O_{2}^{+}} \cdot T\right)^{\frac{1}{2}}} \approx I_{R u O_{3}^{+}} \cdot T^{1 / 2} .
\end{gathered}
$$

These reactions correspond to two different slopes over the entire temperature range when working at a constant ion intensity $\left.\mathrm{I}_{2} \mathrm{O}_{2}^{+}\right)$. These slopes (Figure 2 of Norman et al [23]) give the enthalpies (2nd law method) of reactions (2) and (3).

At higher temperature, using an alumina cell, the molecule $\mathrm{RuO}_{3}(\mathrm{~g})$ is totally decomposed disappearance of the $\mathrm{RuO}_{3}{ }^{+}$ion intensity in the mass spectrum - and the authors [23] observe the evolution of $\mathrm{RuO}_{2}^{+}, \mathrm{RuO}^{+}$and $\mathrm{Ru}^{+}$ion intensities as a function of the oxygen potential followed by the $\mathrm{O}^{+}$coming from the dissociation of oxygen at high temperature according to the reaction,

$$
O_{2}(\mathrm{~g})=2 \mathrm{O}(\mathrm{g})
$$

As the proportion of $\mathrm{O}(\mathrm{g})$ varies with temperature, the authors [23] monitor the main reactions involving $\mathrm{O}_{2}(\mathrm{~g})$ (i.e. $\mathrm{O}_{2}{ }^{+}$ionic intensities) which can be maintained at a constant value when the flow of incoming oxygen is adjusted. Indeed, maintaining the intensity of $\mathrm{O}_{2}{ }^{+}$as a constant value at a given temperature does not allow determining the sensitivity of the mass spectrometer for this species. Based on the assumption of a constant $\mathrm{O}_{2}{ }^{+}$ion intensity, the slopes reflect the following main vaporization reactions,

$$
\begin{gathered}
\mathrm{Ru}(\mathrm{s})+\mathrm{O}_{2}(\mathrm{~g})=\mathrm{RuO}_{2}(\mathrm{~g}) \\
K_{p}(7)=\frac{\mathrm{p}_{R u O_{2}}}{a_{R u} \cdot p_{O_{2}}} \approx \frac{I_{R u O_{2}^{+}} T}{1 \cdot I_{O_{2}^{+}} T} \approx I_{R u O_{2}^{+}} \\
\operatorname{Ru}(\mathrm{s})+1 / 2 \mathrm{O}_{2}(\mathrm{~g})=\mathrm{RuO}(\mathrm{g}) \\
K_{p}(9)=\frac{p_{R u O}}{a_{R u} \cdot p_{O_{2}^{+}}^{1 / 2}} \approx \frac{I_{R u O^{+}}}{1 \cdot\left(I_{O_{2}^{+}} \cdot T\right)^{1 / 2}} \approx I_{R u O^{+}} \cdot T^{1 / 2} .
\end{gathered}
$$

Oxygen potential $\mathrm{p}\left(\mathrm{O}_{2}\right)$ remains fixed at $10^{-4}$ bar (estimated by the authors) whatever the temperature, and the $2^{\text {nd }}$ law (slope) gives the enthalpies of the above reactions.

The parent ion $\mathrm{Ru}^{+}$(measured at an ionization voltage of $10 \mathrm{~V}$ to eliminate any contribution of dissociative ionization of the gaseous oxide species) is not sensitive to oxygen pressure as long as $\mathrm{RuO}_{2}$ (s) is not formed. Indeed, its origin is only due to the vaporization of the sample $\mathrm{Ru}(\mathrm{s})$ as $\mathrm{Ru}(\mathrm{g})$ with an oxygen solubility in $\mathrm{Ru}(\mathrm{s})$ considered negligible (see Chatillon et al [2]). The authors registered the logarithm of the products $I_{R u^{+}} \cdot T$ (in mass spectrometry, these products are 
proportional to the pressure of $\mathrm{Ru}$ ) with respect to the inverse of temperature and, then, calibrated their spectrometer on the known pressure of pure Ru to obtain the mass spectrometer sensitivity related to $\mathrm{Ru}(\mathrm{g})$. Further, sensitivities for oxides are calculated using the maximum ionization cross-section (at $75 \mathrm{~V}$ ) as proposed by Otvos and Stevenson [30] - but applied to their measurement at very low potentials i.e. close to the ionization threshold - and have estimated the efficiency of the multiplier (efficiency(yield) $\approx 1 / \sqrt{ }$ Molar Mass of the ion). They not provide any of their estimated values to re-calculate their sensitivity. However, the use of the maximum ionization cross-sections for such very low ionization potentials can lead to large uncertainties $(\approx$ 2 to 5 times the value of the ion ratios between the different species). Their calibration of the spectrometer leads to the evaluation of the equilibrium constants $K_{p}$ (not published) and consequently the published Gibbs energies which allow the calculation of the reaction entropies at medium temperature by the relation,

$$
\Delta_{r} S_{T}^{\circ}=\mathrm{R} \ln K_{p}+\frac{\Delta_{r} H_{T}^{\circ}}{\mathrm{T}} .
$$

using their published $2^{\text {nd }}$ law reaction enthalpies $\Delta_{r} H_{T}^{\circ}$.

\section{Results}

In this part accurate values for the "thermal" functions (i.e. $\mathrm{C}^{\circ} \mathrm{p}(298 \mathrm{~K}), \mathrm{S}_{298}^{\circ}, \mathrm{H}^{\circ}{ }_{298}-\mathrm{H}^{\circ}{ }_{0}$, - $\left.\left(\mathrm{G}^{\circ}{ }_{\mathrm{T}}-\mathrm{H}^{\circ}{ }_{298}\right) / \mathrm{T}\right)$ allow new and improved third law calculations of the enthalpies of formation for $\mathrm{RuO}_{4}(\mathrm{~g}), \mathrm{RuO}_{3}(\mathrm{~g}) \mathrm{RuO}_{2}(\mathrm{~g})$ and $\mathrm{RuO}(\mathrm{g})$.

\section{1 "Thermal" functions for the gaseous species}

From the literature data presented previously and with our selected molecular parameters for $\mathrm{RuO}_{4}(\mathrm{~g}), \mathrm{RuO}_{3}(\mathrm{~g}), \mathrm{RuO}_{2}(\mathrm{~g})$ and $\mathrm{RuO}(\mathrm{g})$, and using relations proposed in Janaf tables [31] (Rigid Rotator, Harmonic Oscillator) the basic standard data for the "thermal" functions (i.e. $\mathrm{C}^{\circ} \mathrm{p}$ $(298 \mathrm{~K}), \mathrm{S}^{\circ}{ }_{298}, \mathrm{H}^{\circ}{ }_{298}-\mathrm{H}^{\circ}{ }_{0},-\left(\mathrm{G}^{\circ} \mathrm{T}-\mathrm{H}^{\circ}{ }_{0}\right) / \mathrm{T}$ and $\left.-\left(\mathrm{G}^{\circ}{ }_{\mathrm{T}}-\mathrm{H}^{\circ}{ }_{298}\right) / \mathrm{T}\right)$ are presented in Table 1 to Table 4 and compared with those stored in data banks.

Table 1. Heat capacity values for gaseous molecules of $\mathrm{Ru}$-O system ( $\mathrm{RuO}(\mathrm{g}), \mathrm{RuO}_{2}(\mathrm{~g}), \mathrm{RuO}_{3}(\mathrm{~g})$, $\mathrm{RuO}_{4}(\mathrm{~g})$ ) from selected parameters.

\begin{tabular}{|c|c|c|c|c|}
\hline \multirow{2}{*}{ Molecule } & \multicolumn{4}{|c|}{$\mathbf{C}_{\mathbf{p}}^{\circ}(\mathbf{2 9 8 . 1 5}$ K) } \\
& \multicolumn{4}{|c|}{$/ \mathbf{J ~ K}^{\mathbf{- 1}} \mathbf{~ m o l}^{\mathbf{- 1}}$} \\
\cline { 2 - 5 } & This work & $\begin{array}{c}\text { SGPS-SGTE } \\
{[32]}\end{array}$ & TDNucl[33] & $\begin{array}{c}\text { Cordfunke and } \\
\text { Konings [4] }\end{array}$ \\
\hline $\mathrm{RuO}_{4}(\mathrm{~g})$ & 75.188 & 75.814 & 75.596 & $75.188^{*}$ \\
\hline $\mathrm{RuO}_{3}(\mathrm{~g})$ & 61.605 & 59.404 & 59.354 & $61.605^{*}$ \\
\hline $\mathrm{RuO}_{2}(\mathrm{~g})$ & 50.155 & 56.483 & 56.422 & $44.093^{*}$ \\
\hline $\mathrm{RuO}^{*}(\mathrm{~g})$ & 31.503 & 31.358 & 31.463 & 31.544 \\
\hline
\end{tabular}

${ }^{*}$ Calculated value from Cordfunke and Konings [4] molecular parameters 
Table 2. Entropy at $298 \mathrm{~K}$ issued from the present assessment compared to the preceding studies.

\begin{tabular}{|c|c|c|c|c|c|}
\hline \multirow{2}{*}{ Molecule } & \multicolumn{5}{|c|}{ S J K $^{\mathbf{- 1}}$ mol $^{\mathbf{1}}$} \\
\cline { 2 - 6 } & This work & $\begin{array}{c}\text { Cordfunke } \\
\text { and Konings } \\
{[4]}\end{array}$ & $\begin{array}{c}\text { Miradji et al } \\
{[7]} \\
\text { Ab-initio }\end{array}$ & $\begin{array}{c}\text { SGPS-SGTE } \\
{[32]}\end{array}$ & TDNuc1[33] \\
\hline $\mathrm{RuO}_{4}(\mathrm{~g})$ & 280.846 & $280.846^{*}$ & 287.5 & 290.772 & 290.101 \\
\hline $\mathrm{RuO}_{3}(\mathrm{~g})$ & 283.198 & $267.905^{*}$ & 291.0 & 276.253 & 276.143 \\
\hline $\mathrm{RuO}_{2}(\mathrm{~g})$ & 258.938 & $259.162^{*}$ & 266.4 & 267.542 & 267.430 \\
\hline $\mathrm{RuO}(\mathrm{g})$ & 238.138 & $242.212^{*}$ & 242.3 & 242.175 & 242.063 \\
\hline $\mathrm{Ru}(\mathrm{g})$ & $186.4[4]$ & $186.4^{*}$ & 186.6 & 190.946 & 191.055 \\
\hline
\end{tabular}

*Calculated value from Cordfunke and Konings [4] molecular parameters

Table 3. Enthalpy increments $H^{\circ}(298.15)-H^{\circ}(0)$ issued from the present assessment compared to the preceding studies.

\begin{tabular}{|c|c|c|c|c|}
\hline \multirow{2}{*}{ Molecule } & \multicolumn{4}{|c|}{$\begin{array}{c}\mathbf{H}^{\circ}(298.15)-\mathbf{H}^{\circ}(\mathbf{0}) \\
/ \mathrm{J} \mathrm{mol}^{-1}\end{array}$} \\
\hline & This work & SGPS-SGTE [32] & TDNucl[33] & $\begin{array}{c}\text { Corfunke and } \\
\text { Konings [4] }\end{array}$ \\
\hline $\mathrm{RuO}_{4}(\mathrm{~g})$ & 15512.4 & \multirow{4}{*}{ No available data } & \multirow{4}{*}{ No available data } & $15512.4 *$ \\
\hline $\mathrm{RuO}_{3}(\mathrm{~g})$ & 14618.5 & & & $14618.5^{*}$ \\
\hline $\mathrm{RuO}_{2}(\mathrm{~g})$ & 13237.2 & & & $11197.6 *$ \\
\hline $\mathrm{RuO}(\mathrm{g})$ & 8846.6 & & & $8851.2^{*}$ \\
\hline
\end{tabular}

*Calculated value from Cordfunke and Konings [4] molecular parameters

Table 4. Free energy function referred to $0 K$ issued from the present assessment compared to the preceding studies.

\begin{tabular}{|c|c|c|c|c|}
\hline \multirow{2}{*}{ Molecule } & \multicolumn{4}{|c|}{$\begin{array}{c}-\left(\mathbf{G}^{\circ} \mathbf{T}-\mathbf{H}^{\circ}{ }_{\mathbf{0}}\right) / \mathbf{T} \text { at } \mathbf{T}=\mathbf{2 9 8 . 1 5 K} \\
\text { / J K }\end{array}$} \\
\cline { 2 - 5 } & This work & SGPS-SGTE [32] & TDNucl [33] & $\begin{array}{c}\text { Corfunke and } \\
\text { Konings [4] }\end{array}$ \\
\hline $\mathrm{RuO}_{4}(\mathrm{~g})$ & 228.817 & $238.743^{*}$ & $238.073^{*}$ & $228.817^{*}$ \\
\hline $\mathrm{RuO}_{3}(\mathrm{~g})$ & 234.168 & $227.222^{*}$ & $227.113^{*}$ & $234.168^{*}$ \\
\hline $\mathrm{RuO}_{2}(\mathrm{~g})$ & 223.459 & $223.144^{*}$ & $223.033^{*}$ & $221.605^{*}$ \\
\hline $\mathrm{RuO}^{*}(\mathrm{~g})$ & 208.466 & $212.503^{*}$ & $212.392^{*}$ & $212.525^{*}$ \\
\hline
\end{tabular}

*Calculated using our value $\mathrm{H}^{\circ}(298.15)-\mathrm{H}^{\circ}(0)$ form Table 3

To evaluate the impact of some of our parameter choices on the uncertainties - coming from interatomic distance and the electronic levels calculated by quantum chemistry - we performed several calculations of the free energy function $\mathrm{Fef}^{\circ} \mathrm{T}$ used in third law calculations. Comparison 
of the relative difference between the different $\mathrm{Fef}^{\circ}{ }_{\mathrm{T}}$ calculations with these various parameters gives an idea of the expected accuracy related to our selection. The calculated differences are:

a) $\mathrm{RuO}_{4}(\mathrm{~g}):+0.16 \%$ maximum at $6000 \mathrm{~K}$ taking into account the Triplet at $14210 \mathrm{~cm}^{-1}$ instead of a simple sigma state without this level at $14210 \mathrm{~cm}^{-1}$.

b) $\mathrm{RuO}_{3}(\mathrm{~g})$ : $+1.17 \%$ maximum at $6000 \mathrm{~K}$ taking into account or not the Triplet state at $5183 \mathrm{~cm}^{-1}$ and from -0.1 to $-0.06 \%$ between $298 \mathrm{~K}$ and $6000 \mathrm{~K}$ when the interatomic distance decreases towards ab-initio calculations.

c) $\mathrm{RuO}_{2}(\mathrm{~g}):+3.4$ to $+3.0 \%$ maximum between $298 \mathrm{~K}$ and $6000 \mathrm{~K}$ taking into account the Triplet state at $334 \mathrm{~cm}^{-1}$ and from -0.1 to $-0.08 \%$ when the distance decreases towards the ab-initio calculations.

d) $\mathrm{RuO}(\mathrm{g})$ : classical precision of $\pm 0.1 \%$ at $298 \mathrm{~K}$ for a molecule defined by spectroscopy determinations and up to $5 \%$ in the range 4000-5000 K (see Gurvich et al [34]).

\subsection{Formation enthalpies for the gaseous phase}

In this part are exposed new third law calculations performed to obtain formation enthalpies for gaseous molecules $\mathrm{RuO}_{4}(\mathrm{~g}), \mathrm{RuO}_{3}(\mathrm{~g}), \mathrm{RuO}_{2}(\mathrm{~g}), \mathrm{RuO}(\mathrm{g})$ using original literature data from transpiration methods and mass spectrometry.

\subsubsection{Improved results from works using transpiration methods}

\subsubsection{Works of Schäfer et al (1961-1963)}

Compiling Schaffer et al [26] work the present analysis concluded that $\mathrm{RuO}_{4}(\mathrm{~g})$ is the main molecule for temperatures $<1327 \mathrm{~K}$ and that $\mathrm{RuO}_{3}(\mathrm{~g})$ is predominant at higher temperatures. Besides, our so-called "thermal" thermodynamic functions selected for molecules $\mathrm{RuO}_{3}$ and $\mathrm{RuO}_{4}$ are very different from those estimated by Schäfer et al [26]. Then, we can recalculate the $3^{\text {rd }}$ law enthalpies using their total pressure data [26] i.e. values presented in their Table 3 p. 47 , and in pages 50 and 51. This calculation has been done already by Cordfunke and Konings [4] in their compilation.

To improve the accuracy in the determination of formation enthalpies of the two molecules $\mathrm{RuO}_{3}(\mathrm{~g})$ and $\mathrm{RuO}_{4}(\mathrm{~g})$, we resume the analysis of all initial experimental values by using generalized $3^{\text {rd }}$ law calculations on the full data set and in particular by using the total pressure of $\mathrm{Ru}$ species at the same time, i.e. $\mathrm{RuO}_{3}(\mathrm{~g})+\mathrm{RuO}_{4}(\mathrm{~g})$ pressure. The experimental raw values are temperature, imposed oxygen pressure and the ratio between the lost moles of $\mathrm{RuO}_{2}(\mathrm{~s})$ and the elapsed moles of oxygen, corresponding to the volume of the carrier gas. Starting from their Table 3 p. 47 of reference [26], the number of moles of $\mathrm{RuO}_{2}(\mathrm{~s})$ consumed is related to the number of moles of $\mathrm{O}_{2}$ that flushed the reactor during a certain time. Thus, the volume $\mathrm{V}$ of gas $\mathrm{O}_{2}\left(V_{\mathrm{O}_{2}}\right)$ that carried away the oxide $\mathrm{RuO}_{4}(\mathrm{~g})$ will give - according to the stoichiometry of reaction (3) - the loss of a number of moles n' of $\mathrm{RuO}_{2}(\mathrm{~s})$ applying the ideal gas law,

$$
p_{R u O_{4}} V_{O_{2}}=n_{R u O_{4}} R T=n_{R u O_{2}(s)}^{\prime} R T
$$

and for oxygen

$$
p_{O_{2}} V_{O_{2}}=n_{O_{2}} R T
$$

that gives for reaction (3), the ratio 


$$
\frac{p_{R u O_{4}}}{p_{O_{2}}}=\frac{n_{R u O_{2}}^{\prime}}{n_{O_{2}}}
$$

This relationship assumes that the pressure of $\mathrm{RuO}_{4}(\mathrm{~g})$ is relatively low compared to that of $\mathrm{O}_{2}$ ( $<1 \%$ as an upper value) so that the volume of gas $\mathrm{V}$ counted as the volume of $\mathrm{O}_{2}$ is not significantly changed. The equilibrium constant of the reaction (3) will be then:

$$
K_{p}(3)=\frac{p_{R u O_{4}}}{p_{O_{2}}}=\frac{n_{R u O_{2}}^{\prime}}{n_{O_{2}}}
$$

For reaction (2) and according to its stoichiometry and with the measured volume of oxygen swept over the sample, thus the number of gaseous moles transported is,

$$
\begin{gathered}
p_{\mathrm{RuO}_{3}} V_{\mathrm{O}_{2}}=n_{\mathrm{RuO}_{3}} R T=n^{\prime \prime}{ }_{\mathrm{RuO}}(\mathrm{s}) \\
\\
p_{\mathrm{O}_{2}} V_{\mathrm{O}_{2}}=n_{\mathrm{O}_{2}} R T
\end{gathered}
$$

$n^{\prime \prime}$ being, for the same experiment, the number of moles of $\mathrm{RuO}_{2}(\mathrm{~s})$ or $\mathrm{Ru}$ lost in the $\mathrm{RuO}_{3}(\mathrm{~g})$ vaporization for the same $\mathrm{O}_{2}$ volume. This volume $V_{O_{2}}$ is eliminated and the ratio of the pressures remains equal to the ratio of the number of moles,

and reaction (2) equilibrium constant becomes:

$$
\frac{p_{R u O_{3}}}{p_{O_{2}}}=\frac{n^{\prime \prime}{ }_{R u O_{2}}}{n_{O_{2}}}
$$

$$
K_{p}(2)=\frac{p_{R u O_{3}}}{\sqrt{p_{O_{2}}}}=\frac{p_{R u O_{3}}}{p_{O_{2}}} \cdot \sqrt{p_{O_{2}}}=\frac{n^{\prime \prime}{ }_{R u O_{2}}}{n_{O_{2}}} \cdot \sqrt{p_{O_{2}}}
$$

Thus, the total number of moles of $\mathrm{RuO}_{2}$ (s) lost for the same volume of oxygen will be the sum $\mathrm{n}^{\prime}+\mathrm{n}$ ". Introducing $\mathrm{n}$ ' and $\mathrm{n}^{\prime \prime}$ in the previous relationships, $\frac{n_{R u O_{2}}}{n_{O_{2}}}$ becomes

$$
\frac{n_{\mathrm{RuO}_{2}}}{n_{\mathrm{O}_{2}}}=\frac{n^{\prime}+n^{\prime \prime}}{n_{\mathrm{O}_{2}}}=\frac{p_{\mathrm{RuO}_{3}+} p_{\mathrm{RuO}_{4}}}{p_{\mathrm{O}_{2}}} .
$$

Schäfer et al [26] calculate directly from their experimental measured ratio $\frac{n_{\mathrm{RuO}_{2}}}{n_{\mathrm{O}_{2}}}$ the final ratio $\frac{p_{\mathrm{RuO}_{3}+} p_{\mathrm{RuO}_{4}}}{p_{\mathrm{O}_{2}}}$ (as published in their Table 3 ).

Thus, we resume the analysis by checking the ratio of the pressures corresponding to relation (21) with respect to the molar ratio determined in the experiment. The partial pressures in relation (21) are calculated by applying the following two relations of the $3^{\text {rd }}$ law of thermodynamics for reactions (2) and (3),

and

$$
\begin{aligned}
& \Delta_{\text {reac. } 2} H_{298}^{\circ}=-\mathrm{RT} \ln K_{2}+T \Delta_{\text {reac. } 2} F e f_{T}^{\circ} \\
& \Delta_{\text {reac. } 3} H_{298}^{\circ}=-\mathrm{RT} \ln K_{3}+T \Delta_{\text {reac. } 3} F e f_{T}^{\circ}
\end{aligned}
$$




$$
\begin{aligned}
& \ln K_{2}=\frac{p_{R u O_{3}}}{p_{O_{2}}^{1 / 2}}=\frac{-\Delta_{\text {reac. } 2} H_{298}^{\circ}+T \Delta_{\text {reac. } 2} F e f_{T}^{\circ}}{R T} \\
& \ln K_{3}=\frac{p_{R u O_{4}}}{p_{O_{2}}}=\frac{-\Delta_{\text {reac. } 3} H_{298}^{\circ}+T \Delta_{\text {reac. } .3} F e f_{T}^{\circ}}{R T} .
\end{aligned}
$$

Partial pressures in these relationships are expressed in bar. Then, using the oxygen pressures and temperatures of Schäfer et al [26] (from their Table 3), we calculate the pressures of $\mathrm{RuO}_{3}(\mathrm{~g})$ and $\mathrm{RuO}_{4}(\mathrm{~g})$ using our selected free energy functions and arbitrary values for the standard reaction enthalpies. The values of standard enthalpies of the reaction (2) and (3) at $298 \mathrm{~K}$ calculated at two extreme temperatures by Schäfer et al. [27] are used as initial values. Consistency between our calculations of partial pressures by $3^{\text {rd }}$ law and the molar ratio experimental values is checked with relation (21) as a function of temperature. For the initial enthalpies as determined by Schäfer et al [26] we observe at low temperatures - where $\mathrm{RuO}_{4}(\mathrm{~g})$ is the main species - a small relative difference between the two ratios in relation (21) showing that the value of enthalpy of the reaction (3) at $298 \mathrm{~K}$ is quite correct. At high temperatures, the difference is much larger, showing that the initial chosen enthalpy of the reaction (2) is wrong. Next, the standard enthalpies at $298 \mathrm{~K}$ for reactions (2) and (3) are taken as variable parameters to check relation (21). By varying the two reaction enthalpies in steps - method of trial and error - we obtain a data set (see for example Figure 1 ) in which the deviation is minimized over the entire experimental temperature range of Schäfer et al [26]. This minimum is observed for reaction (2) enthalpy fixed at the value proposed below from Penman and Hammer work [28] although the minimum deviation is not very sensitive to variations around this retained value. The deviation also remains more pronounced for high temperatures, i.e. in the range where Schäfer et al [26] proposed $\mathrm{RuO}_{3}(\mathrm{~g})$ as the main molecule. This deviation is more pronounced also in relation to scattered experimental data for instance taken at the same temperature. Moreover, according to enthalpies variation tests, it follows that reaction (2) has greatest influences on the deviations between the experimental moles ratio and the calculated partial pressures ratio (relation (21)). 


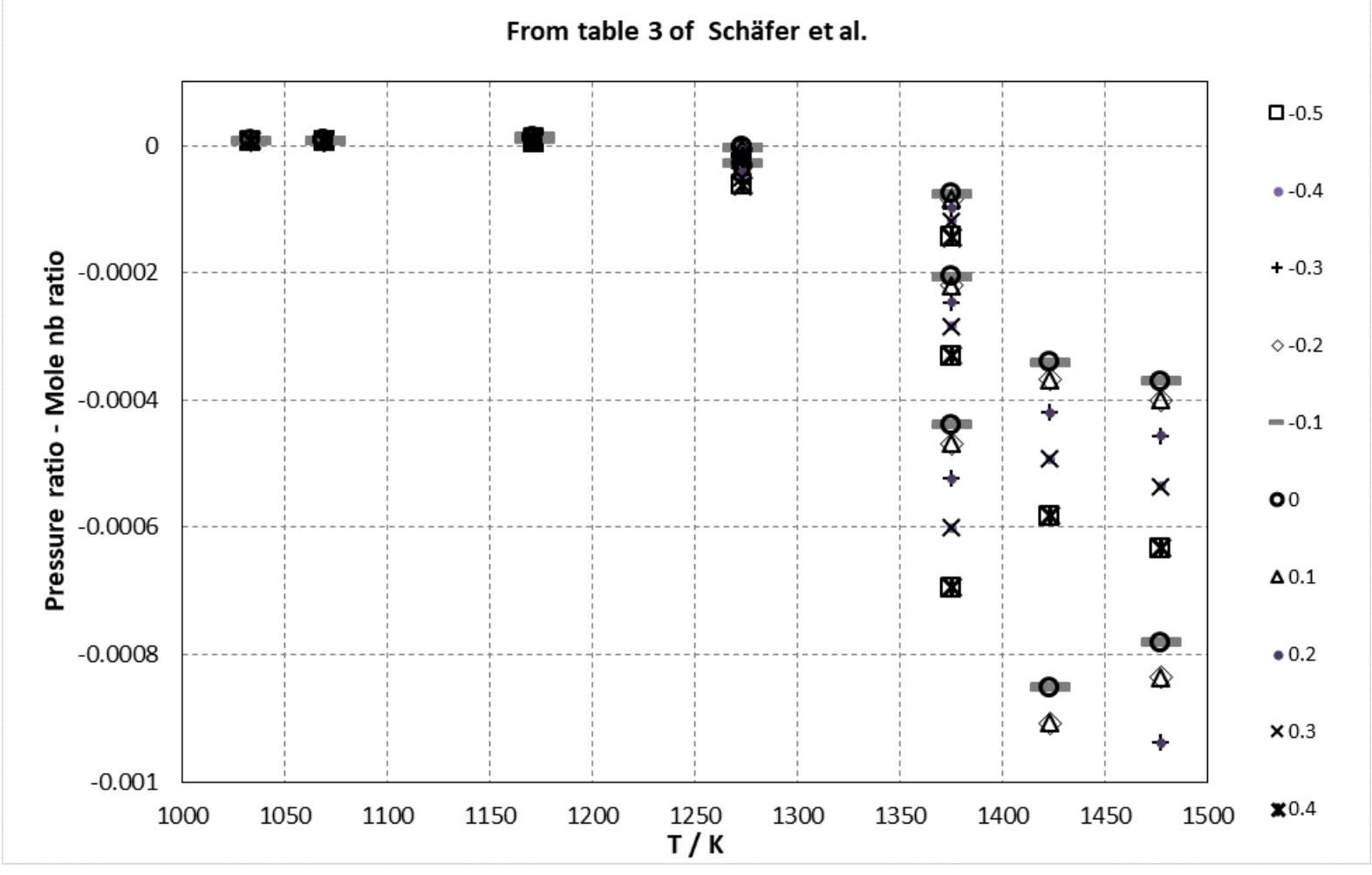

Figure 1: Evolution of the difference between the ratio of the partial pressures $\left(\mathrm{RuO}_{3}(\mathrm{~g})+\right.$ $\left.\mathrm{RuO}_{4}(\mathrm{~g})\right) / \mathrm{O}_{2}(\mathrm{~g})$ calculated via the $3^{\text {rd }}$ law and the ratio of the experimental number of moles published by Schäfer et al [26] (see above relation (21)) as a function of temperature. In the present figure, the numbers at the right side correspond to an index for the variation of the enthalpy of reaction (2) when the enthalpy of reaction (3) is fixed.

The best values of reaction enthalpies that verify relation (21) are,

$$
\begin{aligned}
& \Delta_{\text {reac. } 2} H_{298}^{\circ}(\text { final })=257716 \mathrm{~J} \mathrm{~mol}^{-1} \\
& \Delta_{\text {reac. } 3} H_{298}^{\circ}(\text { final })=114700 \mathrm{~J} \mathrm{~mol}^{-1}
\end{aligned}
$$

These new reactions enthalpies lead to the best standard formation enthalpies of $\mathrm{RuO}_{3}(\mathrm{~g})$ and $\mathrm{RuO}_{4}(\mathrm{~g})$ from the data set of Schäfer et al [26], using our selected formation enthalpy for $\mathrm{RuO}_{2}(\mathrm{~s})=-312.3 \mathrm{~kJ} \mathrm{~mol}^{-1}[2]$,

$$
\begin{gathered}
\Delta_{f} H_{298}^{\circ}\left(\mathrm{RuO}_{3}, g\right)=-54.6 \pm 8.0 \mathrm{~kJ} \mathrm{~mol}^{-1} \\
\Delta_{f} H_{298}^{\circ}\left(\mathrm{RuO}_{4}, g\right)=-197.6 \pm 10.0 \mathrm{~kJ} \mathrm{~mol}^{-1}
\end{gathered}
$$

Total uncertainty includes the uncertainty values in the calculations of $3^{\text {rd }}$ law due to the free energy functions of gaseous species and the sensitivity observed in the method of trial and error to seek the minimum deviation from the two enthalpies taken as variable parameters. 


\subsubsection{Works of Bell and Tagami (1963)}

Bell and Tagami's [27] entropy 2nd law results (Table 5) are compared with the values calculated from our selected entropies. Their reaction entropies are clearly different from the accurate ones we have selected reflecting first the uncertainties associated with their 2nd law treatment.

Table 5. Comparison of entropies of reactions (2) and (3) determined with 2 nd law treatment by Bell and Tagami [27] and our values independently calculated.

\begin{tabular}{|c|c|c|c|c|}
\hline Studied reaction & \multicolumn{3}{|c|}{ Bell et Tagami [27] } & This work \\
\hline & $\begin{array}{c}\mathrm{T} \\
\text { mean } \\
/ \mathrm{K}\end{array}$ & $\begin{array}{c}\Delta_{\mathrm{r}} \mathrm{H}^{\circ} \\
(\mathrm{T} \text { mean }) \\
/ \mathrm{kJ} \mathrm{mol}^{-1}\end{array}$ & $\begin{array}{c}\Delta_{\mathrm{r}} \mathrm{S}^{\circ} \\
\left(\mathrm{T}_{\text {mean }}\right) \\
/ \mathrm{J} \mathrm{K}^{-1} \mathrm{~mol}^{-1}\end{array}$ & $\begin{array}{c}\Delta_{\mathrm{r}} \mathrm{S}^{\circ} \\
\left(\mathrm{T}_{\text {mean }}\right) \\
/ \mathrm{J} \mathrm{K}^{-1} \mathrm{~mol}^{-1}\end{array}$ \\
\hline $\mathrm{RuO}_{2}(\mathrm{~s})+1 / 2 \mathrm{O}_{2}(\mathrm{~g})=\mathrm{RuO}_{3}(\mathrm{~g})$ & 1400 & $214.2 \pm 4.2$ & $94.1 \pm 4.2$ & 102.321 \\
\hline $\mathrm{RuO}_{2}(\mathrm{~s})+\mathrm{O}_{2}(\mathrm{~g})=\mathrm{RuO}_{4}(\mathrm{~g})$ & 1400 & $94.1 \pm 8.4$ & $-0.84 \pm 8.4$ & 3.167 \\
\hline
\end{tabular}

In order to determine the enthalpy values at $298 \mathrm{~K}$ we performed the same $3^{\text {rd }}$ law treatment as in the case of Schäfer et al [26] data. Our calculations start from the original determinations published by Bell and Tagami [27] in their Table I: from the total pressure observed (column 2) associated with the loss of Ru by transport during their experiment, they converted to the sum $\left(\mathrm{p}\left(\mathrm{RuO}_{3}(\mathrm{~g})\right)+\mathrm{p}\left(\mathrm{RuO}_{4}(\mathrm{~g})\right)\right.$ under an oxygen pressure of $1 \mathrm{~atm}$. In fact, this sum is directly related to the number of $\mathrm{RuO}_{2}$ (s) moles lost in the oxygen stream as shown in relation (21). In this study, we use the following relationship for the mole ratio,

$$
\left.\frac{n_{\mathrm{RuO}_{2}}}{n_{\mathrm{O}_{2}}}=\frac{p_{\mathrm{RuO}_{3}+} p_{\mathrm{RuO}_{4}}}{p_{\mathrm{O}_{2}}} \text { (from Bell and Tagami }\right)
$$

where the sum of partial pressures are from table I column 2 issued from Bell and Tagami [27] for an oxygen pressure of $1 \mathrm{~atm}$. In our calculations, we observed that data at $\mathrm{T}>1600 \mathrm{~K}$ never satisfy relation (21) whatever the arbitrary enthalpies introduced for reactions (2) and (3). Moreover, further thermodynamic calculations performed with the present work selected values showed that for $\mathrm{T}>1600 \mathrm{~K}$, equilibrium was established with $\mathrm{Ru}(\mathrm{s})$ and reactions (2) and (3) do not take place. Same features are observed for deviation and scatter as for Schaffer et al [26]. Finally, we retain the data at $\mathrm{T}<1600 \mathrm{~K}$, and the enthalpies of the reactions deduced from the Bell and Tagami [27] transpiration data, are:

$$
\begin{gathered}
\Delta_{\text {reac. } 2} H_{298}^{\circ}=260940 \mathrm{~J} \mathrm{~mol}^{-1} \\
\Delta_{\text {reac. } 3} H_{298}^{\circ}(\text { final })=114700 \mathrm{~J} \mathrm{~mol}^{-1} .
\end{gathered}
$$

These new enthalpies of reactions lead to the standard formation enthalpies of $\mathrm{RuO}_{3}(\mathrm{~g})$ and $\mathrm{RuO}_{4}(\mathrm{~g})$, using our selected formation enthalpy for $\mathrm{RuO}_{2}(\mathrm{~s})=-312.3 \mathrm{~kJ} \mathrm{~mol}^{-1}$ [2],

$$
\begin{gathered}
\Delta_{f} H_{298}^{\circ}\left(\mathrm{RuO}_{3}, g\right)=-51.4 \pm 8.0 \mathrm{~kJ} \mathrm{~mol}^{-1} \\
\Delta_{f} H_{298}^{\circ}\left(\mathrm{RuO}_{4}, g\right)=-197.6 \pm 10.0 \mathrm{~kJ} \mathrm{~mol}^{-1} .
\end{gathered}
$$




\subsubsection{Works of Penman and Hammer (1968)}

From Penman and Hammer [28] data and their hypothesis of the only $\mathrm{RuO}_{4}(\mathrm{~g})$ in the vapor phase, our $2^{\text {nd }}$ and $3^{\text {rd }}$ laws calculations of reaction enthalpy for reaction (3) give:

$$
\begin{gathered}
\Delta_{\text {reac. }} H_{298}^{\circ}(2 \text { nd law })=109.1 \pm 7.1 \mathrm{k} \mathrm{J} \mathrm{mol}^{-1} \\
\Delta_{\text {reac. }} H_{298}^{\circ}(3 \mathrm{rd} \text { law })=114.7 \pm 2.5 \mathrm{k} \mathrm{J} \mathrm{mol}^{-1}
\end{gathered}
$$

Then, using our reference value for $\mathrm{RuO}_{2}(\mathrm{~s})$, the $3^{\text {rd }}$ law standard formation enthalpy of the $\mathrm{RuO}_{4}(\mathrm{~g})$ molecule is

$$
\Delta_{f} H_{298}^{\circ}\left(\mathrm{RuO}_{4}, g\right)=-197.6 \pm 5.5 \mathrm{k} \mathrm{J} \mathrm{mol}^{-1} .
$$

Applying the same $3^{\text {rd }}$ law calculation method as for data of Schäfer at al [26] and Bell and Tagami [27] - taking into account of the two species $\mathrm{RuO}_{3}(\mathrm{~g})$ and $\mathrm{RuO}_{4}(\mathrm{~g})$ in the vapor transport - we observe that calculations from the ratio $\frac{n_{\mathrm{RuO}_{2}}}{n_{\mathrm{O}_{2}}}$ are not sensitive to the variation of formation enthalpy of the $\mathrm{RuO}_{3}(\mathrm{~g})$ molecule from -50 to $0 \mathrm{~kJ} \mathrm{~mol}^{-1}$. We conclude that the $\mathrm{RuO}_{4}(\mathrm{~g})$ molecule is surely the main species present in the vapor.

\subsubsection{Retained thermodynamic data for $\mathrm{RuO}_{4}(\mathrm{~g})$ and $\mathrm{RuO}_{3}(\mathrm{~g})$ molecules}

In the previous compilation, Cordfunke and Konings [4] directly apply $3^{\text {rd }}$ law calculations to published raw partial pressures that lead to large variations in the enthalpies of formation, (-179 to $-190 \mathrm{~kJ} \mathrm{~mol}^{-1}$ for $\mathrm{RuO}_{4}(\mathrm{~g})$, and -60 to $-65 \mathrm{~kJ} \mathrm{~mol}^{-1}$ for $\left.\mathrm{RuO}_{3}(\mathrm{~g})\right)$ with a different reference for $\mathrm{RuO}_{2}$ (s). In the present work, the generalized interpretation by the $3^{\text {rd }}$ law using more accurate free energy functions leads to very close enthalpy results whatever are the authors, a characteristic that is consistent with the usual accuracy of the transpiration method.

The retained value (quoted in table 10) with its uncertainty for $\mathrm{RuO}_{4}(\mathrm{~g})$ comes from Penman and Hammer [28] meanwhile the retained value for $\mathrm{RuO}_{3}(\mathrm{~g})$ is the mean value from Schäfer et al [26] and Bell and Tagami [27] the uncertainty being increased by half their enthalpy difference.

\subsubsection{Improved results from works using mass spectrometry}

Reaction entropies proposed by Norman et al [23] are compared to our calculated reaction entropies in Table 6.

Table 6. Entropies of different reactions derived by Norman et al [23] from their $2^{\text {nd }}$ law calculations and comparison with our selected values

\begin{tabular}{|l|c|c|c|}
\hline \multirow{2}{*}{ Reaction } & \multicolumn{2}{|c|}{$\Delta_{\text {reaction }} \boldsymbol{S}_{T}^{\circ} / \mathbf{J ~ K}^{-\mathbf{1}} \mathbf{~ m o l}^{\mathbf{1}}$} & \multirow{2}{*}{ T range } \\
& $\begin{array}{c}\text { Mean T value } \\
\text { Norman et al. } \\
{[\mathbf{2 3}]}\end{array}$ & This work & \\
\hline $\mathrm{Ru}(\mathrm{s})+3 / 2 \mathrm{O}_{2}(\mathrm{~g})=\mathrm{RuO}_{3}(\mathrm{~g})$ & -87.027 & -56.2 to -56.5 & $1295-1538$ \\
\hline $\mathrm{Ru}(\mathrm{s})+\mathrm{O}_{2}(\mathrm{~g})=\mathrm{RuO}_{2}(\mathrm{~g})$ & -6.276 & 22.1 to 18.1 & $1740-2040$ \\
\hline $\mathrm{Ru}(\mathrm{s})+1 / 2 \mathrm{O}_{2}(\mathrm{~g})=\mathrm{RuO}(\mathrm{g})$ & 49.371 & 89.7 to 86.7 & $1870-2020$ \\
\hline
\end{tabular}


Reaction entropy values at mean experimental temperatures deduced from the experiments by Norman et al [23] clearly disagree with those selected in the same temperature range in this work based on independent determinations of the molecular parameters of gaseous oxides. These discrepancies can come from three different sources: - (i) uncertainties in the calibration of their spectrometer associated with estimates of ionization cross sections (for evaluation of $K_{p}$ ), - (ii) derived $2^{\text {nd }}$ law enthalpies with large uncertainties due to the small temperature ranges for the measurements, or - (iii) out-of-equilibrium steady-state vaporization in their Knudsen cell in relation to evaporation coefficients for at least one of the gaseous species. Consequently, $2^{\text {nd }}$ law enthalpy values proposed by Norman et al [23] cannot be retained and, moreover, no evaluation of their associated uncertainty can be performed. A discussion on the high probability of low evaporation coefficients in the study by Norman et al [23] is presented in Appendix II.

\section{Ionization processes and Born-Haber thermodynamic cycles}

In mass spectrometry studies, identification of species in the gas phase is carried out by monitoring ionization efficiency curves and from the evolution of ions ratios as a function of temperature or composition that allows identifying the molecular origin of the detected ions. At this stage, a combination of different ionization processes can be used to deduce enthalpies for bond breaking using Born-Haber thermodynamic cycles:

- (i) Using adiabatic ionization: the appearance potential (AP) is the potential threshold above which an ion is formed. It is characterized by the ionization potential (IP) for a molecular ion (formerly called "parent" ion),

- (ii) Using dissociative ionization: when a bond break is directly observed from the appearance potential of ions formed (called "fragment ion") or deduced from certain breaks in the ionization efficiency curves. It is characterized by its appearance potential (AP).

For the Ru-O system, different ions as determined in literature by mass spectrometry are presented in Table 7.

Table 7. Ionization and appearance potentials of ions determined by mass spectrometry and their proposed molecular precursors according to literature.

\begin{tabular}{|c|c|c|c|c|}
\hline $\begin{array}{c}\begin{array}{c}\text { Authors (year) } \\
\text { reference }\end{array} \\
\end{array}$ & $\begin{array}{c}\text { Detected } \\
\text { Ions } \\
\end{array}$ & $\begin{array}{l}\text { Appearance } \\
\text { potential / V }\end{array}$ & $\begin{array}{c}\text { Molecular } \\
\text { Origin }\end{array}$ & Comments \\
\hline $\begin{array}{l}\text { Dillard et Kiser } \\
\text { (1965)[35] }\end{array}$ & $\begin{array}{c}\mathrm{RuO}_{4}^{+} \\
\mathrm{RuO}_{3}^{+} \\
- \\
\mathrm{RuO}_{2}^{+} \\
\mathrm{RuO}^{+} \\
\mathrm{Ru}^{+}\end{array}$ & $\begin{array}{r}12.3 \pm 0.2 \\
15.7 \pm 0.3 \\
\quad- \\
14.2 \pm 0.2 \\
18.1 \pm 0.3 \\
22.3 \pm 0.3\end{array}$ & $\begin{array}{c}\mathrm{RuO}_{4} \\
\mathrm{RuO}_{4}+ \\
\mathrm{RuO}_{3} ? \\
\mathrm{RuO}_{4} \\
\mathrm{RuO}_{4} \\
\mathrm{RuO}_{4}\end{array}$ & $\begin{array}{c}\text { Molecular ion } \\
\text { Most abundant on } \mathrm{RuO}_{4}(\mathrm{liq}) \\
\text { Fragment }+ \text { Molecular ion? } \\
\text { Fragment Ion } \\
\text { Fragment Ion } \\
\text { Fragment Ion }\end{array}$ \\
\hline $\begin{array}{c}\text { Norman et al } \\
(1968)[23]\end{array}$ & $\begin{array}{l}\mathrm{RuO}_{4}^{+} \\
\mathrm{RuO}_{3}^{+} \\
\end{array}$ & $\begin{array}{c}12.8 * \\
11.2 \\
\end{array}$ & $\begin{array}{l}\mathrm{RuO}_{4} \\
\mathrm{RuO}_{3} \\
\end{array}$ & $\begin{array}{l}\text { Molecular ion } \\
\text { Molecular ion }\end{array}$ \\
\hline
\end{tabular}




\begin{tabular}{|l|c|c|c|c|}
\hline & $\mathrm{RuO}_{2}^{+}$ & 10.6 & $\mathrm{RuO}_{2}$ & Molecular ion \\
& $\mathrm{RuO}^{+}$ & 8.7 & $\mathrm{RuO}$ & Molecular ion \\
& $\mathrm{Ru}^{+}$ & 7.7 & $\mathrm{Ru}$ & Molecular ion \\
& $\mathrm{Ru}^{+}$ & 13.0 & $\mathrm{RuO}_{2}$ & Fragment ion \\
& $\mathrm{RuO}^{+}$ & 12.8 & $\mathrm{RuO}_{2}$ & Fragment ion \\
\hline
\end{tabular}

$* \pm 0.1 \mathrm{eV}$ our estimate for Norman et al [23].

Norman et al [23] observed breaks in the ionization efficiency curves of $\mathrm{Ru}^{+}$and $\mathrm{RuO}^{+}$for a vapor containing essentially $\mathrm{RuO}_{2}(\mathrm{~g})$. From the measured appearance energy of $\mathrm{RuO}^{+}$ion, the following cycle is used:

$$
\begin{aligned}
& \mathrm{RuO}_{2}(\mathrm{~g})+\mathrm{e}^{-} \rightarrow \mathrm{RuO}^{+}+\mathrm{O}+2 \mathrm{e}^{-} \text {a dissociative ionization } \\
& \mathrm{AP}\left(\mathrm{RuO}^{+} / \mathrm{RuO}_{2}\right)+\mathrm{E}_{\text {kin }}=12.8 \mathrm{eV} \text { at about } 1900 \mathrm{~K} \\
& \mathrm{RuO}(\mathrm{g})+\mathrm{e}^{-} \rightarrow \mathrm{RuO}^{+}+2 \mathrm{e}^{-} \quad \text { an adiabatic ionization } \\
& \mathrm{IP}\left(\mathrm{RuO}^{+} / \mathrm{RuO}\right)=8.7 \mathrm{eV} \text { at about } 1900 \mathrm{~K}
\end{aligned}
$$

where AP is for appearance potential, IP for the ionization potential and $\mathrm{E}_{\mathrm{kin}}$ is for any kinetic energy associated to the neutral species $\mathrm{O}$, a feature that cannot be observed by mass spectrometry. The difference (38)-(39) leads to,

$$
\begin{gathered}
\mathrm{RuO}_{2}(\mathrm{~g})=\mathrm{RuO}(\mathrm{g})+\mathrm{O}(\mathrm{g}) \\
\Delta_{\text {diss. }} H^{\circ}(\mathrm{RuO}-O)+E_{\text {kin }}=4.1 \mathrm{eV}
\end{gathered}
$$

and

$$
\begin{gathered}
\Delta_{\text {diss. }} H_{1900 K}^{\circ}(R u O-O)+E_{\text {kin. }}=395.6 \pm 13.6 \mathrm{~kJ} \mathrm{~mol}^{-1} \\
\text { Or } \Delta_{\text {diss. }} H_{1900 K}^{\circ}(R u O-O) \leq 395.6 \pm 13.6 \mathrm{~kJ} \mathrm{~mol}^{-1}
\end{gathered}
$$

The cycles calculated from the molecules $\mathrm{RuO}_{4}(\mathrm{~g})$ and $\mathrm{RuO}_{2}(\mathrm{~g})$ are compared to final retained thermodynamic values of this work in Table 8 . It should be noted that there is no value for an $\mathrm{Ru}^{+}$ ion coming from $\mathrm{RuO}(\mathrm{g})$ and, therefore, no direct evaluation of the atomization energy of $\mathrm{RuO}(\mathrm{g})$.

Table 8. Dissociation enthalpies of different Metal-Oxygen bonds for the molecules $\mathrm{RuO}_{4}(\mathrm{~g})$ and $\mathrm{RuO}_{2}(\mathrm{~g})$ determined from ionization processes (adiabatic and dissociative) calculated at $298 \mathrm{~K}$ and comparison with the thermochemical values calculated from the formation enthalpies values, analyzed in this work.

\begin{tabular}{|c|c|c|c|c|}
\hline Method & \multicolumn{2}{|c|}{$\begin{array}{c}\text { Energy from the } \\
\text { Ionization processes }\end{array}$} & \multicolumn{2}{c|}{$\begin{array}{c}\text { Energy from thermochemistry } \\
\text { (retained in this work) }\end{array}$} \\
\hline $\begin{array}{c}\text { Bond break } \\
/ \text { From molecule }\end{array}$ & $\begin{array}{c}\boldsymbol{\Delta}_{\text {diss }} \mathbf{H}^{\circ}(\mathbf{T}) \\
/ \mathbf{k J ~ m o l}^{-1}\end{array}$ & $\begin{array}{c}\boldsymbol{\Delta}_{\text {diss }} \mathbf{H}^{\circ}(\mathbf{2 9 8 K}) \\
\mathbf{k J J ~ m o l}^{-1}\end{array}$ & $\begin{array}{c}\boldsymbol{\Delta}_{\text {diss }} \mathbf{H}^{\circ}(\mathbf{2 9 8 K}) \\
/ \mathbf{k J ~ m o l}^{-1}\end{array}$ & $\begin{array}{c}\text { Authors } \\
/ \text { ref }\end{array}$ \\
\hline $\mathrm{RuO}_{3}-\mathrm{O} / \mathrm{RuO}_{4}(\mathrm{~g})$ & $\leq 482.4$ & $\leq 481.4 \pm 20$ & $393.8 \pm 11.4$ & $\begin{array}{c}\text { From retained values } \\
\text { in this work }\end{array}$ \\
\cline { 3 - 5 } & & & 384 & Ab-initio, Miradji et al \\
\hline
\end{tabular}




\begin{tabular}{|c|c|c|c|c|}
\hline & & & & [7] in their Table 8 \\
\hline \multirow[t]{2}{*}{$\mathrm{RuO}-\mathrm{O} / \mathrm{RuO}_{2}(\mathrm{~g})$} & \multirow[t]{2}{*}{$\leq 395.6$} & \multirow[t]{2}{*}{$\leq 391.5 \pm 20$} & $392 \pm 20$ & $\begin{array}{c}\text { From retained values } \\
\text { in this work (Table } \\
10 \text { ) }\end{array}$ \\
\hline & & & 528 & $\begin{array}{c}\text { Miradji et al [7] in } \\
\text { their Table } 8\end{array}$ \\
\hline $\mathrm{Ru}-2 \mathrm{O} / \mathrm{RuO}_{2}(\mathrm{~g})$ & $\leq 511.4$ & $\leq 490.6 \pm 20$ & $1003.4 \pm 20$ & $\begin{array}{c}\text { This work in Table } 90 \\
\text { and } \\
\text { Cordfunke and }\end{array}$ \\
\hline Or $\mathrm{Ru}-\mathrm{O}_{2} / \mathrm{RuO}_{2}(\mathrm{~g})$ & $\leq 511.4$ & $\leq 490.6 \pm 20$ & $505 \pm 20$ & $\begin{array}{c}\text { Konings [4] for } \\
\Delta_{\mathrm{f}} \mathrm{H}^{\circ}(\mathrm{Ru}, \mathrm{g})\end{array}$ \\
\hline
\end{tabular}

For molecule $\mathrm{RuO}_{4}(\mathrm{~g})$, bond breaking energy $\mathrm{RuO}_{3}-\mathrm{O}$ measured by mass spectrometry suggest a large contribution of kinetic energy $(\approx 0.9 \mathrm{eV})$ since the calculated thermochemical value is accurate. For the ionization of the $\mathrm{RuO}_{2}(\mathrm{~g})$ molecule, the dissociative ionization process giving $\mathrm{O}_{2}(\mathrm{~g})$ instead of $2 \mathrm{O}(\mathrm{g})$ seems more probable because the thermochemical value cannot be higher than the one deduced from the ionization process. Note that for the breaking processes of the $\mathrm{RuO}_{2}(\mathrm{~g})$ molecule into $\mathrm{RuO}(\mathrm{g})+\mathrm{O}(\mathrm{g})$, calculated values from thermodynamics and ionization process agree since the ionization process value has been further used (see after).

\section{$3^{\text {rd }}$ law calculations}

Instead of retaining the enthalpies using $2^{\text {nd }}$ law of Norman et al [23] which may be inaccurate due to the small temperature range of measurements and a possible evolution of evaporation coefficients during the experiments (non-equilibrium state in their cells) two possibilities have been taken into account:

- (i) either calculate the original $I_{i}^{+} \cdot T$ (proportional to the partial pressure) from the published figure 4 of Norman et al [23]

- (ii) or re-evaluate the sensitivity of the mass spectrometer with respect to the standard pressure of $\mathrm{Ru}(\mathrm{g})$ and then obtain the equilibrium constants to perform $3^{\text {rd }}$ law calculations.

The measurement of $I_{i}^{+} \cdot T$ products is related to partial pressures through the sensitivity of the mass spectrometer. Therefore, it is possible to relate the ion intensities of $\mathrm{Ru}^{+}$(figure 4 of Norman et al [23]) to the pressure of $\mathrm{Ru}(\mathrm{g})$ over the pure element $\mathrm{Ru}(\mathrm{s})$ knowing that the vaporization of this component is at equilibrium. Indeed, $\mathrm{Ru}(\mathrm{g})$ has no reason to have an evaporation coefficient as shown by Pound [36] when compiling the pure components. As Norman et al [23] use this pressure of $\mathrm{Ru}(\mathrm{g})$ to calibrate their mass spectrometer - combined with the maximum ionization cross-sections (at $75 \mathrm{~V}$ ) estimated by Otvos and Stevenson [30] - we make the same calculation using more recent estimates of the ionization cross-sections by Drowart et al [37] which allow the evaluation of the ionization cross sections at any ionization voltage.

First, the sensitivity $S_{R u}$ of the spectrometer is calculated with the basic spectrometric relationship using the pure $\mathrm{Ru}$ pressure, 


$$
S_{R u}=\frac{I_{R u}^{+} T}{p_{R u}^{\circ}}
$$

Thus, for Ru-oxides, an estimate of sensitivity ratios can be made based on the relationships,

$$
\begin{gathered}
\frac{S_{R u O}}{S_{R u}}=\frac{\sigma_{R u O}}{\sigma_{R u}} \sqrt{\frac{M_{R u}}{M_{R u O}}}=0.65 \times 0.93 \sim 0.6 \\
\frac{S_{R u O_{2}}}{S_{R u}}=\frac{\sigma_{R u O_{2}}}{\sigma_{R u}} \sqrt{\frac{M_{R u}}{M_{R u O_{2}}}}=0.77 \times 0.87 \sim 0.67
\end{gathered}
$$

where the ionization cross-section ratios are taken from the compilation of Drowart et al [37] (in their part 3.4) for oxides of the types $\mathrm{MO}(\mathrm{g})$ and $\mathrm{MO}_{2}(\mathrm{~g})$ with respect to $\mathrm{M}(\mathrm{g})$ metal. The roots of the molar masses come from the type of detector as mentioned by Norman et al [23].The ionization cross-section ratios mentioned in these relationships were established by crossreferencing numerous studies on gaseous oxides for low ionization potentials. For the $\mathrm{RuO} / \mathrm{Ru}$ ionization cross sections ratio we use the above relation (44) since both ions are measured at the same low ionization potential $10 \mathrm{~V}$.

For the ratio of $\mathrm{RuO}_{2} / \mathrm{Ru}$ ionization cross-sections, as the $\mathrm{RuO}_{2}{ }^{+}$ion is measured at $20 \mathrm{~V}$ and the $\mathrm{Ru}^{+}$ion at $10 \mathrm{~V}$ respectively - in fact to avoid contributions of any fragment ions in the ionic intensity evaluation - we estimate directly from the calculated ionization efficiency curves using Drowart et al [37] reference data (reported in Figure 2),

$$
\frac{S_{R u O_{2}}}{S_{R u}}=\frac{\sigma_{R u O_{2}}}{\sigma_{R u}} \sqrt{\frac{M_{R u}}{M_{R u O_{2}}}}=2.96 \times 0.87 \sim 2.57 .
$$

This more accurate estimate differs markedly from the proposed relationship as given in (45). 


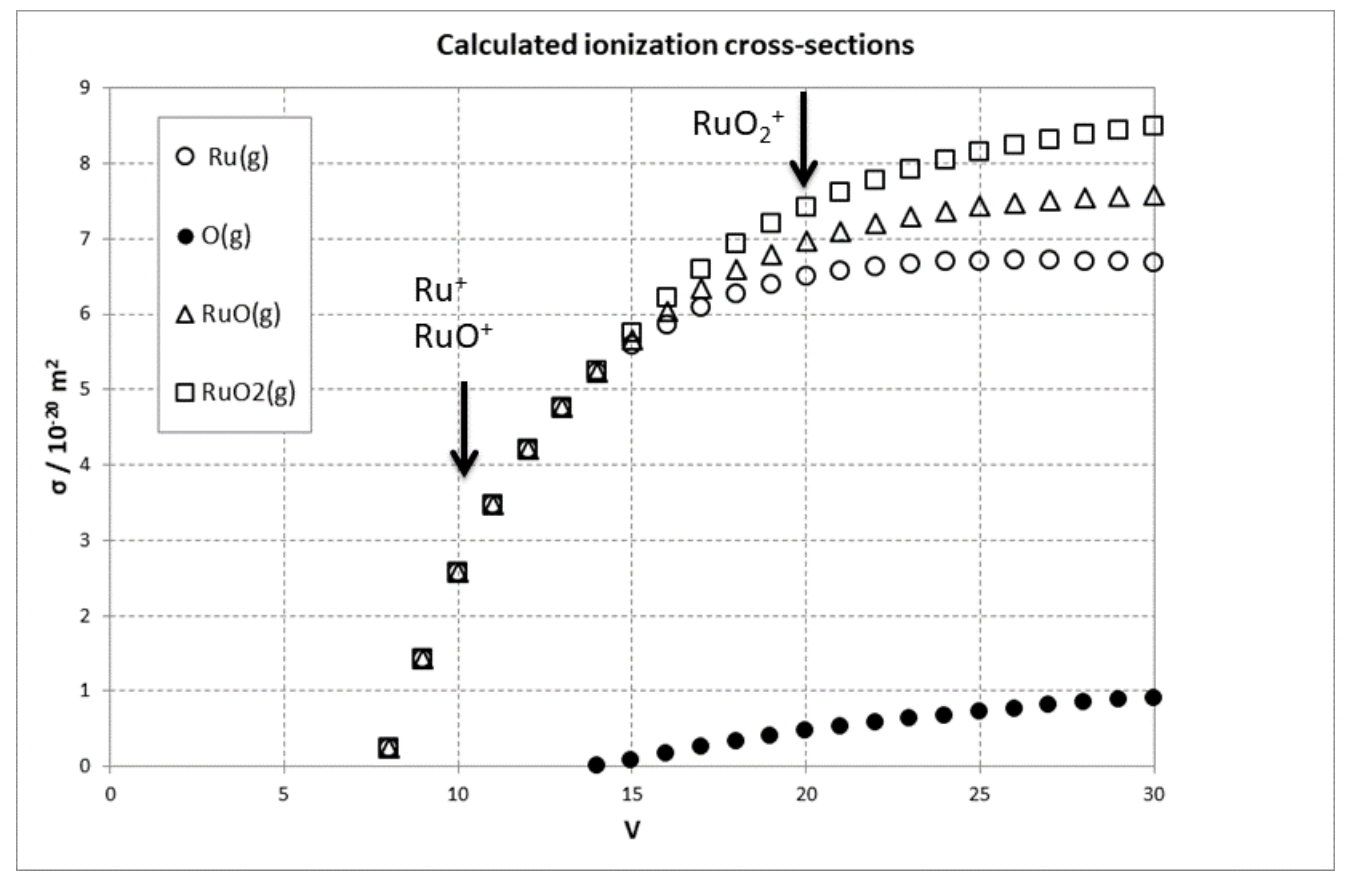

Figure 2: Ionization efficiency curves from Mann calculations and the additivity rule, according to Drowart et al [37]

Using the products $I_{i}^{+} \cdot T^{n}$ from Figure 4 of Norman et al [23] , they are converted into pressureproportional products $I_{i}^{+} \cdot T$ by the spectrometry relationship:

$$
\begin{gathered}
p_{R u O}=\frac{I_{R u O^{+} .} \mathrm{T}}{S_{R u O}} \\
p_{R u O_{2}}=\frac{I_{R u O_{2}^{+}} \cdot T}{S_{R u O_{2}}}
\end{gathered}
$$

and normalized in pressure via their sensitivity,

$$
\begin{aligned}
& \log \left(\mathrm{p}_{R u O}\right)=\log \left(I_{R u O^{+}} \cdot \mathrm{T}^{3 / 4}\right)+\frac{1}{4} \log T+\log S_{R u O} \\
& \log \left(p_{R u O_{2}}\right)=\log \left(I_{R u O_{2}^{+}} \cdot \mathrm{T}^{\frac{1}{2}}\right)+\frac{1}{2} \log T+\log S_{R u O_{2}} \text {. }
\end{aligned}
$$

First, sensitivity of Ru is calculated directly from the products $I_{i}^{+} \cdot T$ derived from Figure 4 of Norman et al [23] and from the standard pressure of $\mathrm{Ru}(\mathrm{g})$ - in equilibrium with the pure $\mathrm{Ru}(\mathrm{s})$ from Cordfunke and Konings [4] compilation. The standard enthalpy of sublimation of $\mathrm{Ru}(\mathrm{s})$ proposed by these authors [4] is $649 \pm 3 \mathrm{~kJ} \mathrm{~mol}^{-1}$ - in agreement with the Hultgren [38] compilation (i.e. $651.4 \pm 4.2 \mathrm{~kJ} \mathrm{~mol}^{-1}$ ). Indeed, this value is not so different from the 2nd law value proposed by Norman et al [23] and recalculated at $298 \mathrm{~K}$ i.e. $639+8=647 \mathrm{~kJ} \mathrm{~mol}^{-1}$. This agreement confirms that the vaporization of $\mathrm{Ru}(\mathrm{g})$ occurs at equilibrium in the experiment. 
Then, partial pressures for $\mathrm{RuO}_{2}(\mathrm{~g})$ and $\mathrm{RuO}(\mathrm{g})$ are re-calculated with our mass spectrometric sensitivity estimates and we perform $2^{\text {nd }}$ and $3^{\text {rd }}$ law calculations (Table 9). In $3^{\text {rd }}$ law calculations, partial pressure of $\mathrm{O}_{2}(\mathrm{~g})$ molecule which enters into equilibrium constant determination is fixed in the range $10^{-3}$ to $10^{-5}$ bar to check the influence of the uncertainty of the pressure of $\mathrm{O}_{2}(\mathrm{~g})$ that is not determined but only estimated at $10^{-4}$ bar by Norman et al [23]. Comparison of the $2^{\text {nd }}$ and $3^{\text {rd }}$ laws (table 9) values shows that some agreement could exist for $\mathrm{RuO}_{2}(\mathrm{~g})$ molecule when increasing slightly the oxygen pressure but this is not possible for $\mathrm{RuO}(\mathrm{g})$. Moreover, trends in $3^{\text {rd }}$ law results observed as a function of temperature let us assume some systematic errors in the determinations of equilibrium constants i.e. presence of some low evaporation coefficients (see Appendix II).

Table 9. 2nd and $3^{\text {rd }}$ law calculations from partial pressure data of Norman et al [23] as corrected in this work from our estimates of ionization cross sections and sensitivity calibration with pure $R u(g)$ pressure.

\begin{tabular}{|c|c|c|c|c|c|}
\hline $\begin{array}{c}\text { Studied reaction } \\
\text { (formation reaction) }\end{array}$ & $\begin{array}{c}2^{\text {nd }} \text { law } \\
\left(\mathbf{T}_{\text {mean }}\right) \\
/ \text { kJ mol }^{-1}\end{array}$ & $\begin{array}{c}2^{\text {nd }} \text { law } \\
(298 K) \\
/ \text { kJ mol }^{-1} \\
\end{array}$ & \multicolumn{3}{|c|}{$\begin{array}{c}3^{\text {rd }} \text { law (298K) } \\
\pm \text { Standard deviation } \\
/ \text { kJ mol }^{-1}\end{array}$} \\
\hline Oxygen pressure in cell & $\begin{array}{l}10^{-4} \text { (est.) } \\
\text { or } \\
\text { constant } \\
\text { /bar }\end{array}$ & $\begin{array}{l}10^{-4} \text { (est.) } \\
\text { or constant } \\
\text { /bar }\end{array}$ & $\begin{array}{l}10^{-3} \\
\text { /bar }\end{array}$ & $\begin{array}{c}10^{-4} \\
/ \text { bar* }\end{array}$ & $\begin{array}{l}10^{-5} \\
/ \mathrm{bar}\end{array}$ \\
\hline $\mathrm{Ru}(\mathrm{s})+\mathrm{O}_{2}(\mathrm{~g})=\mathrm{RuO}_{2}(\mathrm{~g})$ & 118.8 & 139.4 & $165.2 \pm 1.3$ & $129.1 \pm 1.4$ & $93.1 \pm 3.2$ \\
\hline $\begin{array}{l}\mathrm{Ru}(\mathrm{s})+1 / 2 \quad \mathrm{O}_{2}(\mathrm{~g})=\mathrm{RuO} \\
(\mathrm{g})\end{array}$ & 355.6 & 379.7 & $354.9 \pm 9.3$ & $336.8 \pm 8.3$ & $318.8 \pm 7.2$ \\
\hline
\end{tabular}

*this oxygen pressure value is the one estimated by Norman et al [23].

The values of $2^{\text {nd }}$ law may be uncertain because of the small temperature range and the high sensitivity to any slight variation in the evaporation coefficients with temperature. Consequences of low evaporation coefficients as an indicator of non-equilibrium state in the cells are of two kinds:

- The flow of incident oxygen on the surface of Ru sample in the cells provides through a condensation coefficient a decrease of the effective oxygen partial pressure applied to the sample in the cells: the impact of such oxygen lower pressures can be evaluated when looking at the results in Table 9: decreasing the effective oxygen pressure let decrease the deduced enthalpies.

- The existence of evaporation coefficients associated to $\mathrm{RuO}(\mathrm{g})$ and $\mathrm{RuO}_{2}(\mathrm{~g})$ species leading to lower measured partial pressures than equilibrium one - is for instance to increase the third law deduced enthalpies by $38 \mathrm{~kJ}$ compared to equilibrium value (at a mean experimental temperature $=2000 \mathrm{~K}$ ) when the partial pressures in the Knudsen cell decrease by a factor 10 , a value that can be achieved (see Appendix II).

The influence of evaporation and condensation coefficients is thus contradictory since equilibrium constants are based on partial pressure ratios versus oxygen pressures. To verify the 
$3^{\text {rd }}$ law impact due to non-equilibrium state in the Knudsen cells, the above deduced $3^{\text {rd }}$ law (formation) enthalpies must be compared to the maximum binding energies calculated with BornHaber cycles from the ionization processes although these values are known with quite large uncertainties.

For the $\mathrm{RuO}_{2}(\mathrm{~g})$ molecule, the dissociation energy associated with the $\mathrm{Ru}-\mathrm{O}_{2}$ bond (Table 8) leads to the enthalpy of formation:

$$
\begin{aligned}
\Delta_{f} H^{\circ}\left(R u O_{2}, g\right. & 298 \mathrm{~K}) \\
& =\Delta_{f} H^{\circ}(R u, g, 298 \mathrm{~K})-\Delta_{\text {diss.ionization }} H^{\circ}\left(R u-O_{2}, g, 298 \mathrm{~K}\right) .
\end{aligned}
$$

with the enthalpy of formation of $\mathrm{Ru}(\mathrm{g})$ from Cordfunke and Konings [4] (i.e. $649 \pm 3 \mathrm{~kJ} \mathrm{~mol}^{-1}$ ), and the dissociation energy from Table 8 (column 3), it becomes:

$$
\Delta_{f} H^{\circ}\left(R u O_{2}, g, 298 \mathrm{~K}\right)=649-(\leq 490.6)=\geq 158.4 \pm 20 \mathrm{~kJ} \mathrm{~mol}^{-1}
$$

This value could agree with that obtained by mass spectrometry i.e. $129.13^{\text {rd }}$ law (Table 9) at the limit of uncertainty ranges for oxygen pressures around $10^{-4}$ bar, as estimated by Norman et al [23]. Besides, observed difference can have two origins:

- The experimental $3^{\text {rd }}$ law value becomes more compatible with the Born-Haber cycle value if the oxygen pressure is largely higher than estimated in the mass spectrometric experiment but this oxygen increase would be contrary to the probable existence of an oxygen condensation coefficient

- The experimental $3^{\text {rd }}$ law value increases for lower $\mathrm{RuO}_{2}(\mathrm{~g})$ measured pressure values than equilibrium due to kinetic limitation (evaporation coefficient $<1$ ): for a partial pressure decreasing by a factor 10, the experimental deduced enthalpy value 129.1 would result from an already increase of the equilibrium value by $+38 \mathrm{~kJ} \mathrm{~mol}^{-1}$ (see Appendix III) leading to an equilibrium enthalpy far from the 158.4 Born-Haber limit value.

The $3^{\text {rd }}$ law enthalpies calculated using our new calibration remains anomalously low compared to the limit deduced from the Born-Haber cycle and all the more so since any partial pressures deficit due to kinetic limitation should increase this $3^{\text {rd }}$ law value. Thus, we prefer to retain the value deduced from Born-Haber cycles which is really a low limit value:

$$
\Delta_{f} H^{\circ}\left(R u O_{2}, g, 298 \mathrm{~K}\right)=158 \pm 20 \mathrm{~kJ} \mathrm{~mol}^{-1} .
$$

For the process associated with the breaking of the $\mathrm{RuO}-\mathrm{O}$ bond (table 12) and with the above selected value for $\mathrm{RuO}_{2}(\mathrm{~g})$ one obtains:

$$
\begin{aligned}
\Delta_{f} H^{\circ}(R u O, g & 298 \mathrm{~K}) \\
& =\Delta_{\text {diss.ion }} H^{\circ}(R u O-O, g, 298 \mathrm{~K})-\Delta_{f} H^{\circ}(O, g, 298 \mathrm{~K}) \\
& +\Delta_{f} H^{\circ}\left(R u O_{2}, g, 298 \mathrm{~K}\right)
\end{aligned}
$$




$$
\begin{gathered}
\Delta_{f} H^{\circ}(R u O, g, 298 \mathrm{~K})=(\leq 391.5)-249.17+(\geq 158.4) \\
\cong 300.7 \pm 28.3 \mathrm{~kJ} \mathrm{~mol}^{-1} .
\end{gathered}
$$

This last value could agree with the $3^{\text {rd }}$ law formation enthalpy obtained by mass spectrometry (Table 9) due to compensation in kinetic energies of the two dissociative ionization processes that make varying the value of the term 300.7 up and down. The $3^{\text {rd }}$ law value 336.8 is a mean value for experimental data that increase from 325 to 350 (see Appendix III) providing that measured partial pressures are lower than equilibrium ones due to low evaporation coefficient. Consequently, $3^{\text {rd }}$ law enthalpy is over-evaluated (see Appendix III) and the Born-Haber cycle data is preferably retained:

$$
\Delta_{f} H^{\circ}(R u O, g, 298 \mathrm{~K})=301 \pm 28 \mathrm{~kJ} \mathrm{~mol}^{-1} .
$$

\section{Conclusion}

The thermodynamic assessment based on recalculations of the 3rd law carried out in this study allows us to propose a set of formation enthalpy values optimized for ruthenium gaseous oxides with the most probable uncertainties (Table 10). We observed that ab-initio calculations are in agreement with our recalculated value for $\mathrm{RuO}_{3}(\mathrm{~g})$ and $\mathrm{RuO}_{2}(\mathrm{~g})$ while differ from the present value proposed for $\mathrm{RuO}(\mathrm{g})$.

Table 10 Standard formation enthalpies issued from the present assessment compared to the preceding studies.

\begin{tabular}{|c|c|c|c|c|c|}
\hline \multirow{2}{*}{ Compound } & \multicolumn{5}{|c|}{$\Delta_{\boldsymbol{f}} \mathbf{H}_{\mathbf{2 9 8}}^{\circ} / \mathbf{k J ~ m o l}^{-\mathbf{1}}$} \\
\cline { 2 - 6 } & This work & $\begin{array}{c}\text { Cordfunke } \\
\text { and Konings } \\
{[\mathbf{4}]}\end{array}$ & $\begin{array}{c}\text { Miradji et al } \\
\text { [7] } \\
\text { Ab-initio }\end{array}$ & $\begin{array}{c}\text { SGPS-SGTE } \\
{[32]}\end{array}$ & $\begin{array}{c}\text { TDNucl[33 } \\
\text { ] }\end{array}$ \\
\hline $\mathrm{RuO}_{2}(\mathrm{~s})$ & $\mathbf{- 3 1 2 . 3 \pm \mathbf { 0 . 6 } [ \mathbf { 2 } ]}$ & $-314.2 \pm 0.5$ & - & -305.014 & -314.199 \\
\hline $\mathrm{RuO}_{4}(\mathrm{~g})$ & $\mathbf{- 1 9 7 . 6 \pm \mathbf { 5 . 5 }}$ & $-188.0 \pm 4$ & $-188.0 \pm 4 *$ & -184.096 & -183.091 \\
\hline $\mathrm{RuO}_{3}(\mathrm{~g})$ & $\mathbf{- 5 3 . 0 \pm 1 0}$ & $-62.5 \pm 2.5$ & -50 & -78.241 & -78.240 \\
\hline $\mathrm{RuO}_{2}(\mathrm{~g})$ & $\mathbf{1 5 8} \pm \mathbf{2 0}$ & $136 \pm 10$ & 140 & 136.000 & 135.999 \\
\hline $\mathrm{RuO}(\mathrm{g})$ & $\mathbf{3 0 1 \pm \mathbf { 2 8 }}$ & $376 \pm 25$ & 420 & 375.999 & 376.000 \\
\hline $\mathrm{Ru}(\mathrm{g})$ & $\mathbf{6 4 9} \pm \mathbf{3}[\mathbf{4}]$ & $649 \pm 3$ & 639 & 657.950 & 657.950 \\
\hline
\end{tabular}

$*$ Value of Cordfunke and Konings [4] used as a reference.

In order to improve the thermodynamic knowledge of the gaseous phase of $\mathrm{Ru}-\mathrm{O}$ a number of questions remain to be answered:

a) determinations of the total pressure on two-phase $\mathrm{Ru}(\mathrm{s})-\mathrm{RuO}_{2}(\mathrm{~s})$ systematically give higher values than direct measurements of the electromotive force (E.M.F.): in the previous work [2] we chose to select the E.M.F. data because they are all consistent when using very different electrochemical devices and reactions chains, which eliminates the possibility of systematic experimental errors. In the total vapor pressure measurement methods as the static method 
(manometry at cold walls), the total pressure measurement is a measure of the total pressure of the non-condensable species $\mathrm{O}_{2}(\mathrm{~g})$ at walls that is in mechanical equilibrium (given the pressure range $>1$ mbar) with the sum of the pressures at the sample temperature. Condensable vapors are deposited in an intermediate location close to the hot sample, probably not very spread out because in the vapor phases only a very small temperature gradient is necessary to start condensation (of the order of a few degrees). There is then a stationary equilibrium of the diffusion flow between the sample and the nearest condensation site, which ensures a certain back flow of the vapors to the sample. Condensable vapors mainly $\mathrm{RuO}_{4}(\mathrm{~g})$ and $\mathrm{RuO}_{3}(\mathrm{~g})$ - may be the cause of these higher total measured pressures. However, by performing thermodynamic calculations with the current selected data, one obtains the only percentage contribution of these molecules to the total pressure. This is not sufficient to explain the differences between the total pressures and the E.M.F. data.

b) Enthalpy of formation of $\mathrm{RuO}_{2}$ (s) oxide by calorimetry must be accurately determined. Two calorimetric methods can be used - (i) either, by combustion and post-combustion with a more precise analysis of the residue to verify complete combustion, - (ii) or by dissolution techniques which can be more precise when choosing the appropriate chemical bath.

c) Low pressure mass spectrometry determinations with a conventional effusion cell should confirm the presence of $\mathrm{RuO}_{4}(\mathrm{~g})$ and $\mathrm{RuO}_{3}(\mathrm{~g})$ in the vapor phase of $\mathrm{RuO}_{2}(\mathrm{~s})$. However, different tests should be performed with different effusion orifices to control the equilibrium conditions in the cells avoiding any influence of evaporation coefficients on the measured pressures.

d) Vapor pressure data for the sub-oxides $\mathrm{RuO}(\mathrm{g})$ and $\mathrm{RuO}_{2}(\mathrm{~g})$ can only be obtained by mass spectrometric method when introducing small amounts of oxygen on pure $\mathrm{Ru}(\mathrm{s})$ in a Knudsen cell. However, equilibrium conditions have to be checked using different cells geometries and for a wide range of input oxygen pressure. A special oxygen flow device associated with an accurate flow calibration of the mass spectrometer could lead to larger range for observed oxygen pressures and at the same time a larger temperature range for the experiments.

\section{Acknowledgements}

The authors acknowledge the IRSN (France) for financial support (contract number IRSNLS20317). 
4 Appendix I. Literature compilation for molecular parameters for $\mathrm{Ru}-\mathrm{O}$ gaseous molecules.

Table I-1. Literature Interatomic distances in different $\mathrm{RuO}_{n}(\mathrm{~g})(n=1$ to 4$)$ gaseous molecules

\begin{tabular}{|c|c|c|c|c|c|}
\hline Authors & $\underset{/ / \AA}{\mathbf{d}\left(\mathbf{R u}-\mathrm{O}_{4}\right)}$ & $\begin{array}{c}\mathbf{d}(\mathbf{R u}- \\
\left.\mathbf{O}_{\mathbf{3}}\right) \\
/ \AA\end{array}$ & $\begin{array}{c}\mathbf{d}(\mathbf{R u}- \\
\left.\mathbf{O}_{2}\right) \\
/ \AA\end{array}$ & $\begin{array}{c}\mathbf{d}(\mathbf{R u}- \\
\mathbf{O}) \\
/ \AA\end{array}$ & Method \\
\hline Hameka et al.[5] & 1.6083 & 1.6098 & 1.5958 & & Effective Core Potential calculations \\
\hline Siegbahn [6] & 1.67 & 1.68 & 1.67 & & ab-initio calculations \\
\hline Miradji et al [7] & 1.691 & 1.687 & 1.685 & 1.713 & ab-initio calculations \\
\hline Zhou et al [8] & & & 1.697 & & DFT calculations \\
\hline Krauss et Stevens [9] & & & & 1.741 & MC-SCF calculations \\
\hline $\begin{array}{l}\text { Schäfer et al. [10]* } \\
\text { Pley and Wickleder [11] } \\
\text { Scullman and Thelin [12] }\end{array}$ & $\begin{array}{c}1.7058 \\
1.695-1.701\end{array}$ & & & 1.716 & $\begin{array}{l}\text { Gas electron diffraction } \\
\text { XRD (solid) } \\
\text { Band Spectroscopy }\end{array}$ \\
\hline
\end{tabular}

nces at mean temperature $\approx 1200 \mathrm{~K}$. Other methods give theoretical values at $0 \mathrm{~K}$.

Table I-2. Molecular parameters of $\mathrm{RuO}_{4}(\mathrm{~g})$

\begin{tabular}{|c|c|c|c|c|c|c|c|c|c|c|}
\hline Authors & Method & $\begin{array}{c}\text { Symmetry } \\
\text { group }\end{array}$ & $\begin{array}{c}\text { Electronic } \\
\text { State } \\
/ \mathrm{cm}^{-1}\end{array}$ & $\mathbf{r}_{\mathbf{R u}-O}$ & $\begin{array}{c}\text { Bond angles } \\
\rho^{\circ}\end{array}$ & $\begin{array}{c}v_{1} \\
(1) \\
/ \mathbf{c m}_{1}^{-}\end{array}$ & $\begin{array}{l}v_{2}(2) \\
/ \mathrm{cm}^{-1}\end{array}$ & $\begin{array}{l}v_{3}(3) \\
/ \mathrm{cm}^{-1}\end{array}$ & $\begin{array}{l}v_{4}(3) \\
/ \mathrm{cm}^{-}\end{array}$ & Comments \\
\hline $\begin{array}{l}\text { Braune and } \\
\text { Stute } \\
(1938)[14]\end{array}$ & $\begin{array}{l}\text { Electron } \\
\text { diffraction }\end{array}$ & $\begin{array}{c}\text { Regular } \\
\text { tetrahedral } \\
\mathrm{T}_{\mathrm{d}}(\sigma=12)\end{array}$ & & 1.66 & & & & 920.8 & & \\
\hline $\begin{array}{l}\text { Dodd } \\
(1959)[17]\end{array}$ & $\begin{array}{l}\text { IR } \\
\text { spectroscopy }\end{array}$ & $\begin{array}{c}\text { Regular } \\
\text { tetrahedral }\end{array}$ & & 2.23 calc. & & $\begin{array}{l}880 \\
\text { calc }\end{array}$ & & 920 & & \\
\hline
\end{tabular}




\begin{tabular}{|c|c|c|c|c|c|c|c|c|}
\hline & & $\mathrm{T}_{\mathrm{d}}$ & & $\begin{array}{c}\text { ulate } \\
\text { d }\end{array}$ & & & & \\
\hline $\begin{array}{l}\text { Ortner } \\
(1961)[18]\end{array}$ & $\begin{array}{l}\text { Adsorption } \\
\text { Spectra } \\
650-5000 \\
300-500 \mathrm{~cm}^{-1}\end{array}$ & $\mathrm{~T}_{\mathrm{d}}$ & & 880 & 293 & 913 & 330 & \\
\hline $\begin{array}{l}\text { Schäfer (1967) } \\
\text { [10] }\end{array}$ & $\begin{array}{l}\text { Electron } \\
\text { diffraction }\end{array}$ & $\mathrm{T}_{\mathrm{d}}$ & $\begin{array}{c}1.7058 \pm \\
0.003\end{array}$ & & & & & $\begin{array}{l}\text { Vibration } \\
\text { amplitudes } \\
\text { agree with } \\
\text { spectroscop } \\
\text { ic results }\end{array}$ \\
\hline $\begin{array}{l}\text { McDowell et al. } \\
\text { (1972)[15] }\end{array}$ & $\begin{array}{l}\text { IR and } \\
\text { Raman } \\
\text { spectra with } \\
{ }^{18} \mathrm{O} /{ }^{16} \mathrm{O} \\
\text { isotopes }\end{array}$ & $\mathrm{T}_{\mathrm{d}}$ & $\begin{array}{l}1.706 \text { est. } \\
\text { from } \\
\text { Schäfer[10 } \\
]\end{array}$ & $\begin{array}{c}885 . \\
3\end{array}$ & 319 & 921 & 336 & $\begin{array}{l}\text { Vapor, } \\
\text { Liquid } \\
\text { and } \mathrm{RuO}_{4} \\
\text { dissolved in } \\
\mathrm{CCl}_{4} \\
v_{3} \text { band } \\
\text { contour } \\
\text { analysis }\end{array}$ \\
\hline $\begin{array}{l}\text { Königer and } \\
\text { Müller } \\
\text { (1977)[19] }\end{array}$ & $\begin{array}{l}\text { IR } \\
\text { spectroscopy } \\
\text { Matrix } \\
\text { isolation. } \\
{ }^{104} \mathrm{Ru} /{ }^{99} \mathrm{Ru} \\
\text { isotopes }\end{array}$ & & $\begin{array}{l}1.706 \text { est. } \\
\text { from } \\
\text { Schäfer[10 } \\
\text { ] }\end{array}$ & & & $\begin{array}{c}\text { 919.2 } \mathrm{Ar} \\
923.4 \\
\text { vapor }\end{array}$ & & $\begin{array}{l}\text { vapor phase } \\
v_{3} \text { band } \\
\text { contour } \\
\text { analysis }\end{array}$ \\
\hline $\begin{array}{l}\text { Kay et al. } \\
\text { (1989)[16] }\end{array}$ & $\begin{array}{l}\text { FTIR } \\
\text { spectroscopy } \\
\text { with } \\
{ }^{18} \mathrm{O} /{ }^{16} \mathrm{O} \text { in } \\
\text { Ar Matrix }\end{array}$ & $T_{d}$ & & & & 920.8 & & \\
\hline $\begin{array}{l}\text { Green et al. } \\
(1989) \text { [13] }\end{array}$ & $\begin{array}{l}\text { FTIR Matrix } \\
\text { Isolation in }\end{array}$ & $\begin{array}{c}\mathrm{Td} \\
\text { Undistorte }\end{array}$ & & $\begin{array}{l}882 . \\
5\end{array}$ & & $\begin{array}{l}916.9 \\
\text { obs. }\end{array}$ & & $\begin{array}{l}\text { From } \\
\text { Vapor }\end{array}$ \\
\hline
\end{tabular}




\begin{tabular}{|c|c|c|c|c|c|c|c|c|c|c|}
\hline & $\begin{array}{l}\text { Ar. } \\
{ }^{16} \mathrm{O}-{ }^{18} \mathrm{O} \\
\text { isotopes }\end{array}$ & $\begin{array}{c}\mathrm{d} \\
\text { Confirmed } \\
\text { by FG } \\
\text { matrix } \\
\text { calculation } \\
\text { s }\end{array}$ & & & & calc. & & $\begin{array}{l}915.9 \\
\text { calc. }\end{array}$ & & $\mathrm{RuO}_{4}$ \\
\hline $\begin{array}{l}\text { Hameka et al. } \\
\text { (1991)[5] }\end{array}$ & $\begin{array}{l}\text { Effective } \\
\text { Core } \\
\text { Potential } \\
\text { calculations } \\
\text { Vibration } \\
\text { frequencies }\end{array}$ & $\mathrm{T}_{\mathrm{d}}$ & & 1.6083 & & 1055 & 398 & 923 & 413 & $\begin{array}{l}\text { Use of } \\
\text { effective } \\
\text { core } \\
\text { potentials } \\
\text { in } \\
\text { "Gaussian } \\
90 \text { Prog. } \\
\text { Pack." }\end{array}$ \\
\hline $\begin{array}{l}\text { Siegbahn } \\
\text { (1993)[6] }\end{array}$ & $\begin{array}{l}\text { ab-initio } \\
\text { calculations }\end{array}$ & $\mathrm{T}_{\mathrm{d}}$ & ${ }^{1} \mathrm{~A}_{1}$ & 1.67 & & & & & & $\begin{array}{l}\text { Influence of } \\
4 \mathrm{~d} \text { orbitals } \\
\text { filling as a } \\
\text { function of } \\
\text { the number } \\
\text { of } \mathrm{O}\end{array}$ \\
\hline $\begin{array}{l}\text { Zhou et al. } \\
\text { (2000)[8] }\end{array}$ & $\begin{array}{l}\text { Ru Laser } \\
\text { ablation } \\
\text { under } \mathrm{O}_{2} \\
\text { Trap in Ar or } \\
\text { Ne matrix. } \\
\text { IR spectra } \\
\text { and DFT } \\
\text { calculations }\end{array}$ & $T_{d}$ & & & & & & $\begin{array}{l}916.9 \\
(\mathrm{Ar}) \\
923(\mathrm{Ne}) \\
\\
950.2\end{array}$ & & \\
\hline $\begin{array}{l}\text { Pley and } \\
\text { Wickleder, } \\
(2005)[11]\end{array}$ & $\begin{array}{l}\text { XRD on } \\
\text { condensed } \\
\mathrm{RuO}_{4} \text { solids } \\
\text { from } \mathrm{KReO}_{4} \\
\text { vaporization }\end{array}$ & $\begin{array}{l}\text { Cubic } \\
\text { symmetry } \\
\text { P4 group } \\
\text { Monoclini } \\
\text { c }\end{array}$ & & $\begin{array}{l}1.695 \\
\\
1.697- \\
1.701 \\
\end{array}$ & $\begin{array}{l}109.3 \\
108.9-110.1\end{array}$ & & & & & $\begin{array}{l}\text { Basic } \\
\text { tetrahedron } \\
\mathrm{RuO}_{4} \\
\text { Very small } \\
\text { deformation }\end{array}$ \\
\hline
\end{tabular}




\begin{tabular}{|c|c|c|c|c|c|c|c|c|c|c|}
\hline & & $\begin{array}{l}\text { symmetry } \\
\text { C2 group }\end{array}$ & & & & & & & & \\
\hline $\begin{array}{l}\text { F. Miradji et al. } \\
\text { (2015) [7] }\end{array}$ & $\begin{array}{l}\text { Ab-initio } \\
\text { Calculations } \\
\text { TPSSh- } \\
\text { 5\%HF }\end{array}$ & $\mathrm{T}_{\mathrm{d}}$ & $\begin{array}{l}{ }^{1} \mathrm{~A}_{1} \text { and } \\
\text { Triplet state } \\
\text { at } \\
170 \mathrm{~kJ} \mathrm{~mol}^{-} \\
{ }^{1}= \\
14210 \mathrm{~cm}^{-1}\end{array}$ & 1.691 & & 952 & 327 & 974.3 & 350 & \\
\hline \multirow[t]{2}{*}{ This work } & \multirow[t]{2}{*}{ Selected } & \multirow[t]{2}{*}{$\mathbf{T}_{\mathrm{d}}$} & \multirow[t]{2}{*}{$\begin{array}{l}\mathrm{g}_{0}=1 \quad \varepsilon_{0}=0 \\
\mathrm{~g}_{1}=3 \\
\varepsilon_{1}=\mathbf{1 4 2 1 0}\end{array}$} & $\begin{array}{l}1.7058 \quad \pm \\
0.003 \\
\text { From } \\
\text { Schäfer } \\
{[10] \text { E.D. }} \\
\text { Slightly } \\
\text { more than } \\
\text { DRX on } \\
\text { solids }\end{array}$ & $\begin{array}{l}109.471^{\circ} \\
\text { Undistorted } \\
\text { tetrahedral } \\
\text { from Greene } \\
\text { et al[13] }\end{array}$ & \multirow{2}{*}{$\begin{array}{l}885 . \\
3 \\
\text { Mea } \\
\text { S. by } \\
\text { Mc } \\
\text { Dow } \\
\text { ell } \\
{[15]} \\
\text { Mat } \\
\text { rix } \\
\text { Isola } \\
\text { tion }\end{array}$} & \multirow[t]{2}{*}{$\begin{array}{l}319 \\
\text { Meas. } \\
\text { by Mc } \\
\text { Dowell } \\
\text { [15]Ma } \\
\text { trix } \\
\text { Isolatio } \\
\text { n }\end{array}$} & \multirow[t]{2}{*}{$\begin{array}{l}921 \\
\text { Meas. } \\
\text { by Mc } \\
\text { Dowell } \\
{[15] \text { Mat }} \\
\text { rix } \\
\text { Isolation }\end{array}$} & \multirow[t]{2}{*}{$\begin{array}{l}336 \\
\text { Meas } \\
\text { ' by } \\
\text { Mc } \\
\text { Dow } \\
\text { ell } \\
{[15]} \\
\text { Matr } \\
\text { ix } \\
\text { Isola } \\
\text { tion }\end{array}$} & \multirow{2}{*}{$\begin{array}{l}\text { Selection } \\
\text { based on } \\
\text { main } \\
\text { experiment } \\
\text { al features } \\
\text { Electronic } \\
\text { structure } \\
\text { as } \\
\text { calculated } \\
\text { by } \\
\text { quantum } \\
\text { chemistry }\end{array}$} \\
\hline & & & & \multicolumn{2}{|c|}{$\begin{array}{c}\mathrm{I}_{\mathrm{A}} \mathrm{I}_{\mathrm{B}} \mathrm{I}_{\mathrm{C}} * / \mathrm{cgs} \\
=8.75900 \cdot 10^{-114}\end{array}$} & & & & & \\
\hline
\end{tabular}

${ }^{*} \mathrm{I}_{\mathrm{A}} \mathrm{I}_{\mathrm{B}} \mathrm{I}_{\mathrm{C}}$ calculated using the selected values for interatomic distances and bond angle

Table I-3. Molecular parameters of $\mathrm{RuO}_{3}(\mathrm{~g})$

\begin{tabular}{|c|c|c|c|c|c|c|c|c|c|c|}
\hline Authors & Method & $\begin{array}{c}\text { Symmetry } \\
\text { Group }\end{array}$ & $\begin{array}{l}\text { Elec. } \\
\text { State } \\
/ \mathrm{cm}^{-1}\end{array}$ & $\begin{array}{c}\mathbf{r}_{\text {Ru-O }} \\
/ \AA\end{array}$ & $\begin{array}{c}\text { Bond } \\
\text { angles }\end{array}$ & $\begin{array}{l}v_{1}(1) \\
/ \mathrm{cm}^{-1}\end{array}$ & $\begin{array}{l}v_{2}(2) \\
/ \mathrm{cm}^{-1}\end{array}$ & $\begin{array}{l}v_{3}(2) \\
/ \mathrm{cm}^{-1}\end{array}$ & $\begin{array}{l}v_{4}(1) \\
/ \mathrm{cm}^{-1}\end{array}$ & Comments \\
\hline $\begin{array}{l}\text { Kay et al. } \\
(1989) \text { [16] }\end{array}$ & $\begin{array}{l}\text { FTIR } \\
\text { spectroscopy } \\
\text { with } \\
{ }^{18} \mathrm{O} /{ }^{16} \mathrm{O} \text { i n } \\
\text { Ar Matrix } \\
\text { Isolation }\end{array}$ & $\begin{array}{c}\mathrm{D}_{3 \mathrm{~h}} \\
\text { (assumed } \\
\text { planar) } \\
\sigma=6\end{array}$ & & & $120^{\circ}$ & $\begin{array}{c}950.1(1) \\
\text { (estimated) }\end{array}$ & & $\begin{array}{c}893.4 \\
(2)\end{array}$ & & $\begin{array}{l}\text { Calculated } \\
\text { force } \\
\text { constants } \\
\text { High } \\
\text { resolution } \\
\text { due to } \\
\text { isotopes }\end{array}$ \\
\hline
\end{tabular}




\begin{tabular}{|c|c|c|c|c|c|c|c|c|c|c|}
\hline $\begin{array}{l}\text { Hameka et } \\
\text { al. } \\
\text { (1991)[5] }\end{array}$ & $\begin{array}{l}\text { Effective Core } \\
\text { Potential } \\
\text { calculations } \\
\text { Vibration } \\
\text { frequencies }\end{array}$ & $\mathrm{D}_{3 \mathrm{~h}}$ & & 1.6098 & $120^{\circ}$ & 1054.9(1) & $329.8(2)$ & $758.6(2)$ & 185.0(1) & \\
\hline $\begin{array}{l}\text { Siegbahn } \\
\text { (1993)[6] }\end{array}$ & $\begin{array}{l}\text { ab-initio } \\
\text { calculations }\end{array}$ & $\mathrm{D}_{3 \mathrm{~h}}$ & ${ }^{1} \mathrm{~A}_{1}$ & 1.68 & & & & & & $\begin{array}{l}\text { Influence of } \\
4 \mathrm{~d} \text { orbitals } \\
\text { filling as } \\
\text { function of } \\
\text { the oxygen } \\
\text { number }\end{array}$ \\
\hline $\begin{array}{l}\text { Zhou et } \\
\text { al. } \\
(2000) \text { [8] }\end{array}$ & $\begin{array}{l}\text { Ru Laser } \\
\text { ablation under } \\
\mathrm{O}_{2} \\
\text { Trapping in Ar } \\
\text { or Ne matrix. } \\
\text { IR spectra } \\
\text { and DFT } \\
\text { calculations }\end{array}$ & $\begin{array}{c}\mathrm{C}_{3 \mathrm{v}} \\
\text { deduced } \\
\text { from anti- } \\
\text { symmetric } \\
v_{3} \\
\mathrm{D}_{3 \mathrm{~h}}\end{array}$ & ${ }^{1} \mathrm{~A}_{1}$ & & & & & $\begin{array}{c}954.0 \\
\text { and } \\
953.4 \\
\\
\\
974.9\end{array}$ & & $\begin{array}{l}\text { Vibrations } \\
\text { deduced } \\
\text { from } C_{3 v} \\
\text { structure } \\
\text { assumption }\end{array}$ \\
\hline $\begin{array}{l}\text { F. Miradji } \\
\text { et al. } \\
(2015)[7]\end{array}$ & $\begin{array}{l}\text { Ab-initio } \\
\text { Calculations } \\
\text { TPSSh-5\%HF }\end{array}$ & $\mathrm{D}_{3 \mathrm{~h}}$ & $\begin{array}{c}{ }^{\mathrm{I}} \mathrm{A}_{1} \text { and } \\
\text { Triplet } \\
\text { state at } \\
62 \mathrm{~kJ} \\
\mathrm{~mol}^{-1}= \\
5183 \mathrm{~cm}^{-} \\
1\end{array}$ & 1.687 & $120^{\circ}$ & 963.9 & 298.2 & 963 & 71.3 & \\
\hline \multirow[t]{2}{*}{ This work } & \multirow[t]{2}{*}{ Selected } & \multirow[t]{2}{*}{$\begin{array}{c}D_{3 h} \\
\sigma=6\end{array}$} & \multirow[t]{2}{*}{$\begin{array}{l}\mathrm{g}_{0}=1 \quad \varepsilon_{0}=0 \\
\mathrm{~g}_{1}=3 \\
\varepsilon_{1}=\mathbf{5 1 8 3}\end{array}$} & $\begin{array}{c}1.7058 \\
\pm \\
0.003 \\
\text { As } \\
\text { RuO4 }\end{array}$ & $120^{\circ}$ & \multirow[t]{2}{*}{950.1} & \multirow[t]{2}{*}{298.2} & \multirow[t]{2}{*}{893.4} & \multirow[t]{2}{*}{71.3} & \multirow[t]{2}{*}{$\begin{array}{l}\text { Retained } \\
\text { Frequencies } \\
\text { from Kay et } \\
\text { al[16] and } \\
\text { Miradji et } \\
\text { al[7] }\end{array}$} \\
\hline & & & & $\mathrm{I}_{\mathrm{A}} \mathrm{I}_{\mathrm{B}} \mathrm{I}_{\mathrm{C}}$ & $\operatorname{logs}$ & & & & & \\
\hline
\end{tabular}




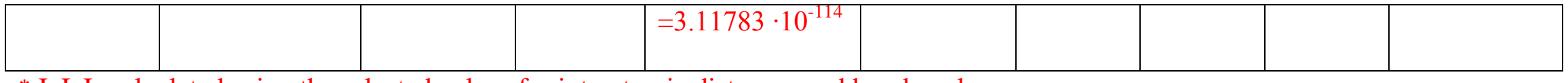

* $\mathrm{I}_{\mathrm{A}} \mathrm{I}_{\mathrm{B}} \mathrm{I}_{\mathrm{C}}$ calculated using the selected values for interatomic distances and bond angle

Table I- 4. Molecular parameters of $\mathrm{RuO}_{2}(\mathrm{~g})$

\begin{tabular}{|c|c|c|c|c|c|c|c|c|c|}
\hline Authors & Method & $\begin{array}{l}\text { Symmetry } \\
\text { Group } \\
(\sigma) \\
\end{array}$ & $\begin{array}{c}\text { Electronic } \\
\text { State } \\
/ \mathrm{cm}^{-1} \\
\end{array}$ & $\mathbf{r}_{\mathbf{R u}-O}$ & $\underset{/^{\circ}}{\text { Angle }}$ & $\begin{array}{l}v_{1}(1) \\
/ \mathrm{cm}^{-1}\end{array}$ & $\begin{array}{l}v_{2}(1) \\
/ \mathbf{c m}^{-}\end{array}$ & $\begin{array}{l}v_{3}(1) \\
/ \mathrm{cm}^{-1}\end{array}$ & Comments \\
\hline $\begin{array}{l}\text { Kay et al. } \\
(1989)[16]\end{array}$ & $\begin{array}{l}\text { FTIR } \\
\text { spectroscopy with } \\
{ }^{18} \mathrm{O} /{ }^{16} \mathrm{O} \text { in } \\
\text { Ar Matrix } \\
\text { Isolation }\end{array}$ & $\begin{array}{c}\mathrm{C}_{2 \mathrm{v}} \\
\sigma=2\end{array}$ & & & $\begin{array}{c}149 \pm \\
2^{\circ}\end{array}$ & 926 & & 902.2 & $\begin{array}{l}\text { Full isotopic resolution } \\
\text { Calculated force constants }\end{array}$ \\
\hline $\begin{array}{l}\text { Hameka et } \\
\text { al. } \\
(1991)[5]\end{array}$ & $\begin{array}{l}\text { Effective Core } \\
\text { Potential } \\
\text { calculations } \\
\text { Vibration } \\
\text { frequencies }\end{array}$ & $\mathrm{C}_{2 \mathrm{v}}$ & $\begin{array}{l}\text { Close singlet } \\
\text { states } \\
\text { Triplet at } 42.4 \\
\qquad \mathrm{~kJ} \mathrm{~mol} \\
=3547 \mathrm{~cm}^{-1}\end{array}$ & 1.5953 & $150.6^{\circ}$ & 1098.2 & 308.6 & 817.2 & \\
\hline $\begin{array}{l}\text { Siegbahn } \\
(1993)[6]\end{array}$ & $\begin{array}{l}\text { ab-initio } \\
\text { calculations }\end{array}$ & $\mathrm{C}_{2 \mathrm{v}}$ & ${ }^{1} \mathrm{~A}_{1}$ & 1.67 & $152.8^{\circ}$ & & & & $\begin{array}{l}\text { Influence of } 4 d \text { orbitals } \\
\text { filling as a function of the } \\
\text { number of Oxygen }\end{array}$ \\
\hline $\begin{array}{l}\text { Zhou et al. } \\
\text { (2000) [8] }\end{array}$ & $\begin{array}{l}\text { Ru Laser ablation } \\
\text { under } \mathrm{O}_{2} \text { and } \\
\text { trapping in Ar or } \\
\text { Ne matrix. IR } \\
\text { spectra } \\
\text { and } 2 \text { DFT } \\
\text { calculations }\end{array}$ & $\mathrm{C}_{2 \mathrm{v}}$ & ${ }^{1} \mathrm{~A}_{1}$ & 1.697 & $\begin{array}{c}150 \pm 1^{\circ} \\
\mathrm{Ne}\end{array}$ & $\begin{array}{c}924.7 \\
\left({ }^{102} \mathrm{Ru}\right)\end{array}$ & & $\begin{array}{c}876.5 \\
\mathrm{Ne} \\
\left({ }^{102} \mathrm{Ru}\right) \\
989.7- \\
990.1 \\
\left({ }^{102} \mathrm{Ru}\right)\end{array}$ & $\begin{array}{l}\text { Symmetric and anti- } \\
\text { symmetric vibrations are } \\
\text { not in agreement between } \\
\text { experiment and DFT calc. }\end{array}$ \\
\hline
\end{tabular}




\begin{tabular}{|c|c|c|c|c|c|c|c|c|c|}
\hline $\begin{array}{l}\text { F. Miradji } \\
\text { et al. } \\
(2015)[7]\end{array}$ & $\begin{array}{l}\text { Ab-initio } \\
\text { Calculations } \\
\text { TPSSh-5\%HF }\end{array}$ & $\mathrm{C}_{2 \mathrm{v}}$ & $\begin{array}{c}{ }^{1} \mathrm{~A}_{1} \\
\text { Lowest triplet } \\
\text { state at } \\
4 \mathrm{~kJ} \mathrm{~mol}^{-1}= \\
334 \mathrm{~cm}^{-1}\end{array}$ & 1.685 & $149.8^{\circ}$ & 972.4 & 191.7 & 964.4 & \\
\hline This work & Selection & $\begin{array}{l}C_{2 v} \\
\sigma=2\end{array}$ & $\begin{array}{l}\mathrm{g}_{0}=1 \quad \varepsilon_{0}=0 \\
\mathrm{~g}_{1}=3 \\
\varepsilon_{1}=334 \mathrm{~cm}^{-1}\end{array}$ & $\begin{array}{c}\mathbf{1 . 7 0 5 8} \\
\text { Same } \\
\text { distance } \\
\text { as in } \\
\mathbf{R u O}_{4} \\
\mathrm{I}_{\mathrm{A}} \mathrm{I}_{\mathrm{B}} \mathrm{I} \\
=1.6\end{array}$ & $\begin{array}{l}\text { /cgs } \\
249\end{array}$ & 926 & 180 & 902.2 & $\begin{array}{l}v_{2} \text { frequency scaled to } v_{1} \\
\text { and } v_{3} \text { between Miradji et } \\
\text { al[7] and experimental } \\
\text { values of Kay et al[16] }\end{array}$ \\
\hline
\end{tabular}

${ }^{*} \mathrm{I}_{\mathrm{A}} \mathrm{I}_{\mathrm{B}} \mathrm{I}_{\mathrm{C}}$ calculated using the selected values for interatomic distances and bond angle

Table I-5. Molecular parameters of $\mathrm{RuO}(\mathrm{g})$

\begin{tabular}{|c|c|c|c|c|c|c|c|c|c|}
\hline Authors & $\begin{array}{c}\text { Experimental } \\
\text { Methods }\end{array}$ & $\begin{array}{c}\text { Electronic } \\
\text { States } \\
\varepsilon_{\mathrm{i}} / \mathrm{cm}^{-1} \\
\end{array}$ & $\begin{array}{c}\mathbf{r}_{\text {Ru-O }} \\
/ \AA\end{array}$ & $\begin{array}{c}\omega_{\mathrm{e}} \\
/ \mathrm{cm}^{-1}\end{array}$ & $\begin{array}{c}\omega_{\mathrm{e}} \mathrm{X}_{\mathrm{e}} \\
/ \mathrm{cm}^{-1}\end{array}$ & $\begin{array}{c}\mathbf{B}_{\mathrm{e}} \\
/ \mathrm{cm}^{-1}\end{array}$ & $\begin{array}{c}\alpha_{\mathrm{e}} \\
/ \mathrm{cm}^{-1}\end{array}$ & $\begin{array}{c}D_{e} \\
/ \mathrm{cm}^{-1}\end{array}$ & Comments \\
\hline $\begin{array}{l}\text { Raziunas } \\
\text { et al. } \\
(1965) \text { [20] }\end{array}$ & $\begin{array}{l}\text { Atomic Emission } \\
\text { Spectroscopy } \\
\text { Band system } \\
\text { analysis }\end{array}$ & $\begin{array}{l}{ }^{3} \Sigma^{+} \\
g_{0}=3 \quad \varepsilon_{0}=0 \\
{ }^{3} \Sigma^{+} \rightarrow X \text { at } \\
18876.1\end{array}$ & 1.70 & 880.8 & 13.1 & 0.422 & & & \\
\hline $\begin{array}{l}\text { Scullman } \\
\text { and Thelin } \\
(1975)[12]\end{array}$ & $\begin{array}{l}\text { Atomic Emission } \\
\text { Spectroscopy } \\
(5000 \text { to } 6800 \AA) \\
\text { Band system } \\
\text { analysis }\end{array}$ & $\begin{array}{l}\text { Transition } \\
\text { around } \\
17000- \\
18000\end{array}$ & 1.716 & 863.5 & 4.6 & 0.4137 & 0.0028 & 0.3 & $\begin{array}{l}\text { Refined analysis } \\
\text { compared to preceding } \\
\text { one from Raziunas et al. } \\
{[20]}\end{array}$ \\
\hline
\end{tabular}




\begin{tabular}{|c|c|c|c|c|c|c|c|c|c|}
\hline $\begin{array}{l}\text { Krauss } \\
\text { and } \\
\text { Stevens } \\
(1985)[9]\end{array}$ & $\begin{array}{l}\text { Quantum } \\
\text { chemistry } \\
\text { MC-SCF with } \\
\text { Relativistic } \\
\text { Effective } \\
\text { Potentials. } \\
\end{array}$ & $\begin{array}{l}{ }^{5} \Delta \\
\mathrm{g}_{0}=10 \quad \varepsilon_{0}=0\end{array}$ & 1.741 & 814 & 5.0 & & & & \\
\hline $\begin{array}{l}\text { Kay et al. } \\
(1989)[16]\end{array}$ & $\begin{array}{l}\text { FTIR } \\
\text { spectroscopy with } \\
{ }^{18} \mathrm{O} / /^{16} \mathrm{O} \text { in } \\
\text { Ar Matrix }\end{array}$ & & & 839 & 1.8 & & & & $\begin{array}{l}\text { Full isotopic resolution } \\
\text { Force constants calculated }\end{array}$ \\
\hline $\begin{array}{l}\text { Zhou et } \\
\text { al. }(2000) \\
\text { [8] }\end{array}$ & $\begin{array}{l}\text { Ru Laser ablation } \\
\text { and co-deposition } \\
\text { with } \mathrm{O}_{2} \text { in } \mathrm{Ar} \text { or } \\
\mathrm{Ne} \text { matrix. IR } \\
\text { spectra } \\
\text { and DFT } \\
\text { calculations }\end{array}$ & ${ }^{5} \Delta$ & & $\begin{array}{c}834.2(\mathrm{Ar}) \\
849.7 \\
(\mathrm{Ne}) \\
859.9- \\
862.7\end{array}$ & & & & & \\
\hline $\begin{array}{l}\text { F. Miradji } \\
\text { et al. } \\
\text { (2015) [7] }\end{array}$ & $\begin{array}{l}\text { Ab-initio } \\
\text { Six different } \\
\text { calculations }\end{array}$ & ${ }^{5} \Delta$ & $\begin{array}{c}1.709- \\
1.721 \\
1.713 \\
\text { retained } \\
\end{array}$ & $\begin{array}{l}895 \\
\text { retained }\end{array}$ & & & & & \\
\hline $\begin{array}{l}\text { Gaydon } \\
(1968)[21]\end{array}$ & $\begin{array}{l}\text { Compiled from } \\
\text { Raziunas et al. } \\
\text { (1965) [20] }\end{array}$ & & & & & & & & $\mathrm{D}^{\circ}=175.7 \pm 1.7 \mathrm{~kJ} \mathrm{~mol}^{-1}$ \\
\hline $\begin{array}{l}\text { Hüber and } \\
\text { Hertzberg } \\
(1995)[22]\end{array}$ & $\begin{array}{l}\text { Compilation from } \\
\text { Scullman and } \\
\text { Thelin } \\
\text { (1975) [12] }\end{array}$ & $\begin{array}{l}\mathrm{A}_{1} \\
\text { Obs. } \\
\text { Transition at } \\
\mathrm{g}_{1}=1 \\
\varepsilon_{1}=18024 \\
\end{array}$ & $1.716(8)$ & 863.5 & 4.6 & 0.4137 & 0.0028 & 3 & $\begin{array}{l}\mathrm{D}^{\circ}{ }_{0}=511.3 \mathrm{~kJ} \mathrm{~mol}^{-1} \\
\text { from Norman et al (1968) } \\
{[23]}\end{array}$ \\
\hline This work & Our selection $^{\mathrm{a}}$ & $\begin{array}{l}\mathrm{g}_{0}=3 \varepsilon_{0}=0 \\
\mathrm{~g}_{1}=3 \\
\varepsilon_{1}=17500\end{array}$ & 1.716 & 863.5 & 4.6 & $0.4137 *$ & 0.0028 & 0.3 & $\begin{array}{l}\text { Exp }^{\text {al }} \text { values from } \\
\text { Raziunas et al [20] and } \\
\text { Scullman and Thelin[12] }\end{array}$ \\
\hline
\end{tabular}




\section{Appendix II. Vapor pressures and evaporation coefficients.}

Evaporation coefficients were originally defined by comparing under vacuum the free vaporization flows $F_{i}$ of a surface with those calculated or measured at equilibrium with an effusion cell. The evaporation coefficient $\alpha$ for a gaseous species $i$ is defined as follows either from molecular flows $F$ or from measured pressures $p$,

$$
\alpha_{i}=\frac{F_{i}^{\text {free }}}{F_{i}^{e q}}=\frac{p_{i}^{\text {free }}}{p_{i}^{\text {eq }}}
$$

per unit of surface (free surface or cross-section of the effusion orifice). Coefficients values $\alpha_{i}=1$ are for equilibrium conditions and $\alpha_{i}<1$ are for any surface vaporizing with a kinetic barrier. Any low evaporation coefficient existing at the sample surface in an effusion cell will causes any pressure drop. Thus, pressures measured with the Knudsen cell method by mass spectrometry can be schematically represented in Figure II- 1 . The evaporation coefficients may be constant as a function of the inverse of temperature or may show a logarithmic variation similar to Arrhenius law -. Therefore, a vapor pressure determined by effusion method leads either to a curve parallel to the equilibrium curve or to a curve reaching equilibrium values at high temperature. Experimental pressure parallel to equilibrium pressure corresponds to any entropy barrier associated with the kinetics of species formation in the adsorbed layer before evaporation (frequency factor in the Arrhenius law) while a non-parallel line reflects two combined effects - enthalpy barrier (activation) and entropy barrier.

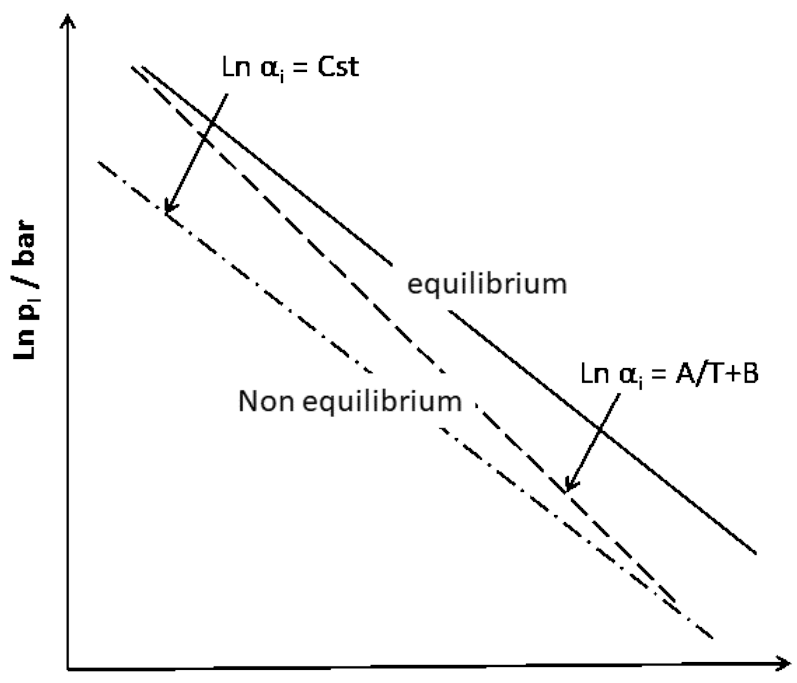

$1 /(\mathrm{T} / \mathrm{K})$

Figure II-1. Effect of the presence of a kinetic limitation in the vaporization reactions at the surface of the sample - presence of an evaporation coefficient $\alpha_{i}$ - on the partial pressures measured by effusion mass spectrometry. 
For $\mathrm{RuO}_{3}(\mathrm{~g})$ molecule, the $2^{\text {nd }}$ law enthalpy of reaction (4) proposed by Norman et al. [23] is quite close to original determinations of Schäfer et al [26] and Bell and Tagami [27], whereas the entropy obtained in their publication after spectrometer calibration is clearly different from that calculated from our selection. We can conclude that an evaporation coefficient is associated with this molecule, and that it is a constant value as a function of temperature due to similar enthalpy values (similar slopes). Under these conditions, the calculations of the $3^{\text {rd }}$ law that we have made from the Gibbs energy data of Norman et al [23] lead to trends in standard enthalpies as a function of temperature.

Assuming constant evaporation coefficients, the value of the pressure difference measured in the effusion cell relative to the equilibrium pressure can be deduced from the following two relationships applied to their vaporization reactions:

(i) at equilibrium with the thermodynamic functions ( standard $^{\circ}$ ):

$$
-R T \ln p_{e q}=\Delta_{r} H_{T}^{\circ}-T \Delta_{r} S_{T}^{\circ}
$$

(ii) for the measurements in non-equilibrium with a kinetic limitation $(*)$ :

$$
-R T \ln p_{\text {meas }}=R T \ln \beta p_{e q}=\Delta_{r} H_{T}^{*}-T \Delta_{r} S_{T}^{*}
$$

The $\beta$ coefficient reflects the pressure deficit in the cell $(\beta \leq 1)$ due to $\alpha$ evaporation coefficient at the sample surface $(\alpha \leq 1)$. The relationship between the two coefficients $\alpha$ and $\beta$ is generally deduced from the Motzfeldt's relationship [39] (see also Heyrman et al [40]) who established it by considering the steady-state flows in effusion cells. In the present case, the effusion pressure deficit - coefficient $\beta$ - can be evaluated from the entropies calculated at equilibrium with respect to the experimental entropies published by Norman et al [23] in their page 107,

$$
\ln \beta=\frac{\Delta_{r} S_{T}^{*}-\Delta_{r} S_{T}^{\circ}}{R}
$$

which gives the following values in table II- 1 for the different species.

Table II-1. Partial pressure ratio ( $\beta=$ measured pressure / equilibrium pressure) for $\mathrm{RuO}_{3}(\mathrm{~g})$, $\mathrm{RuO}_{2}(\mathrm{~g}), \mathrm{RuO}(\mathrm{g})$ and estimated evaporation coefficient $\alpha$.

\begin{tabular}{|c|c|c|c|}
\hline & $\mathrm{RuO}_{3}(\mathrm{~g})$ & $\mathrm{RuO}_{2}(\mathrm{~g})$ & $\mathrm{RuO}(\mathrm{g})$ \\
\hline $\ln \beta$ & -3.586 & -3, & -4.706 \\
& & .210 & \\
\hline$\beta$ & 0.028 & 0.040 & 0.009 \\
\hline$\alpha$ & $2.810^{-4}$ & $4.210^{-4}$ & $\approx 10^{-4}$ \\
\hline
\end{tabular}

Using the reactions entropies, the $\beta$ coefficients are effectively $<1$, which surely reflects a kinetic limitation of the vaporization reactions. Applying the Motzfeldt's relation for an arbitrarily orthocylindrical effusion cell that relates the theoretical equilibrium pressure to the measured pressure,

$$
p_{e q}=p_{\text {meas }}\left(1+\frac{f}{\alpha}\right)
$$


and with a usual ratio $\mathrm{f}=\mathrm{sC} / \mathrm{S}=10^{-2}$ ( $\mathrm{s}$ is the area of orifice and $\mathrm{C}$ the Clausing coefficient of the effusion orifice, $\mathrm{S}$ the cross section of the cell) we obtain a value of the evaporation coefficient $\alpha$ mentioned in the last row of Table II-1. These coefficients are very low and unlikely at least for $\mathrm{RuO}(\mathrm{g})$ which does not really require significant surface rearrangement in the adsorbed layer. There is probably - (i) in the value of the coefficient $\beta$ some uncertainty in the spectrometer pressure calibration procedure, and - (ii) in the equilibrium constants an uncertainty in the applied pressure of $\mathrm{O}_{2}(\mathrm{~g})$ since the authors estimated it to be about $10^{-4}$ bar but did not calibrate it. Moreover, the $\mathrm{O}_{2}(\mathrm{~g})$ molecule when it arrives at the surface of $\mathrm{Ru}$ must dissociate to form an adsorbed $\mathrm{O}_{a d s}$ species and the reaction can be limited kinetically (the so-called condensation coefficient $<1$ ). Insufficient $\mathrm{O}_{\text {ads }}$ adsorption concentration at the surface is equivalent to an oxygen potential deficit at the surface of $\mathrm{Ru}$ in the Knudsen cell sample. At this point, the production of gaseous oxides is reduced and contributes to the decrease of partial pressures compared to those expected at equilibrium. Therefore, a part of the value of the coefficient $\beta$ is explained in this way.

\section{Appendix III. 3rd law calculations with Norman et al [23] original data}

Starting from $\Delta_{\mathrm{r}} \mathrm{H}^{\circ}(\mathrm{T})$ and $\Delta_{\mathrm{r}} \mathrm{S}^{\circ}(\mathrm{T})$ proposed by Norman et al [23] as issued from $2^{\text {nd }}$ law we calculate the function $\Delta_{r} G^{\circ}(T)$ for arbitrarily different temperature increments in their available temperature range and consequently the equilibrium constant is deduced:

$$
\Delta_{r} G^{\circ}(T)=\Delta_{r} H^{\circ}(T)-T \cdot \Delta_{r} S^{\circ}(T)=-R T \ln K_{p}(T)
$$

From the equilibrium constant, $3^{\text {rd }}$ law enthalpy values are calculated using our retained free energy functions

$$
\Delta_{r} H^{\circ}(T)=-R T \ln K_{p}(T)+T \cdot \Delta_{r} F e f^{\circ}(T)
$$

and presented in Table III- 1 . We observe a trend in the deduced $3^{\text {rd }}$ law enthalpies as a function of temperature in place of a statistic distribution around a mean value. Consequently, one of the two terms of the $3^{\text {rd }}$ law relationship is misjudged. Since our free energy functions are well known, it is likely that the equilibrium constants or partial pressures are poorly evaluated. Moreover, the enthalpies of the $2^{\text {nd }}$ law of Norman et al. [23] corrected at $298 \mathrm{~K}$ using our selected thermal functions (enthalpy increments) largely disagree with the enthalpies values of the $3^{\text {rd }}$ law.

Table III-1. $3^{\text {rd }}$ law formation enthalpies at $298 \mathrm{~K}$ for ruthenium gaseous oxides obtained from the values of the equilibrium constants calculated according to enthalpies and entropies provided by Norman et al. [23] $2^{\text {nd }}$ law treatment. The free energy functions are those compiled in this work.

\begin{tabular}{|c|c|c|c|}
\hline \multicolumn{4}{|c|}{$\mathbf{R u}(\mathbf{s})+\mathbf{3 / 2} \mathbf{O}_{\mathbf{2}}(\mathbf{g})=\mathbf{R u O} \mathbf{O}_{\mathbf{3}}(\mathbf{g})$} \\
\hline $\mathbf{T} / \mathbf{K}^{*}$ & $\ln \mathbf{K p}$ & $\boldsymbol{\Delta}_{\mathbf{r}} \mathbf{F e f}(\mathbf{T}) / \mathbf{J ~ K}^{-1}$ & $\begin{array}{c}\boldsymbol{\Delta}_{\mathbf{f}} \mathbf{H}^{\circ}(\mathbf{2 9 8} \mathbf{K}) / \mathbf{~ k J} \\
\pm \text { Standard deviation }\end{array}$ \\
\hline 1285 & -3.810 & & -30.476 \\
1300 & -3.886 & -55.392 & -29.978 \\
\hline
\end{tabular}




\begin{tabular}{|c|c|c|c|}
\hline 1350 & -4.130 & -55.299 & -28.294 \\
\hline 1400 & -4.356 & -55.209 & -26.582 \\
\hline 1450 & -4.567 & -55.111 & -24.850 \\
\hline 1500 & -4.764 & -55.012 & -23.105 \\
\hline 1538 & -4.905 & -54.940 & -21.777 \\
\hline \multicolumn{3}{|c|}{ Mean value \pm standard deviation } & $-26.4 \pm 3.4$ \\
\hline & & 2nd law at $298 \mathrm{~K}$ & $-60.7 * *$ \\
\hline \multicolumn{4}{|c|}{$\mathbf{R u}(\mathrm{s})+\mathrm{O}_{2}(\mathrm{~g})=\mathrm{RuO}_{2}(\mathrm{~g})$} \\
\hline 1740 & -8.968 & 29.264 & 180.7 \\
\hline 1800 & -8.694 & 29.060 & 182.4 \\
\hline 1850 & -8.480 & 28.867 & 183.8 \\
\hline 1900 & -8.277 & 28.654 & 185.2 \\
\hline 1850 & -8.480 & 28.867 & 183.8 \\
\hline 2000 & -7.901 & 28.167 & 187.7 \\
\hline 2040 & -7.760 & 27.953 & 188.6 \\
\hline \multicolumn{3}{|c|}{ Mean value \pm standard deviation } & $184.6 \pm 2.8$ \\
\hline & & 2nd law at $298 \mathrm{~K}$ & $139.4 \pm 4.2 * *$ \\
\hline \multicolumn{4}{|c|}{$\operatorname{Ru}(\mathrm{s})+1 / 2 \mathrm{O}_{2}(\mathrm{~g})=\mathrm{RuO}(\mathrm{g})$} \\
\hline 1870 & -16.936 & 98.311 & 447.2 \\
\hline 1900 & -16.574 & 98.153 & 448.3 \\
\hline 1950 & -15.997 & 97.891 & 450.3 \\
\hline 2000 & -15.449 & 97.630 & 452.2 \\
\hline 2020 & -15.237 & 97.527 & 452.9 \\
\hline \multicolumn{3}{|c|}{ Mean value \pm standard deviation } & $450.2 \pm 2.4$ \\
\hline & & 2nd law at $298 \mathrm{~K}$ & $355.6 \pm 20.9 * *$ \\
\hline
\end{tabular}

*Temperatures are chosen arbitrarily but included in the temperature range of the experiment. **Values and uncertainty listed according to Norman et al. [23]

Table III-2. $3^{\text {rd }}$ law formation enthalpies at $298 \mathrm{~K}$ for ruthenium gaseous oxides obtained from new partial pressures calculated from Norman et al. [23] figures and our mass spectrometric calibration procedure. The free energy functions are those compiled in this work.

\begin{tabular}{|c|c|c|c|}
\hline \multicolumn{4}{|c|}{$\mathrm{Ru}(\mathrm{s})+\mathrm{O}_{2}(\mathrm{~g})=\mathrm{RuO}_{2}(\mathrm{~g})$} \\
\hline $\mathbf{T} / \mathbf{K}^{*}$ & $\ln \mathrm{Kp}$ & $\Delta_{\mathrm{r}} \operatorname{Fef}(\mathrm{T}) / \mathrm{J} \mathrm{K}^{-1}$ & $\begin{aligned} & \Delta_{\mathrm{f}} \mathbf{H}^{\circ}(298 \mathrm{~K}) / \mathrm{kJ} \\
\pm & \text { Standard deviation }\end{aligned}$ \\
\hline 1736 & -5.523 & 29.275 & 130.6 \\
\hline 1782 & -5.357 & 29.124 & 131.3 \\
\hline 1843 & -4.929 & 28.897 & 128.8 \\
\hline 1884 & -4.817 & 28.725 & 129.6 \\
\hline 1926 & -4.519 & 28.536 & 127.3 \\
\hline 1976 & -4.389 & 28.293 & 128.0 \\
\hline 2038 & -4.215 & 27.962 & 128.4 \\
\hline \multicolumn{3}{|c|}{ Mean value \pm standard deviation } & $129.1 \pm 1.4$ \\
\hline & & 2nd law at $298 \mathrm{~K}$ & $134.2 \pm 4.2 * *$ \\
\hline \multicolumn{4}{|c|}{$\operatorname{Ru}(\mathrm{s})+1 / 2 \mathrm{O}_{2}(\mathrm{~g})=\mathrm{RuO}(\mathrm{g})$} \\
\hline
\end{tabular}




\begin{tabular}{|l|c|c|c|}
\hline 1736 & -10.601 & 99.295 & 325.5 \\
1782 & -10.278 & 99.082 & 328.9 \\
1843 & -9.942 & 98.784 & 334.3 \\
1884 & -9.712 & 98.570 & 337.8 \\
1926 & -9.334 & 98.345 & 338.8 \\
1976 & -9.068 & 98.065 & 342.7 \\
2038 & -8.897 & 97.698 & 349.9 \\
\hline \multicolumn{3}{|c|}{ Mean value \pm standard deviation } & $\mathbf{3 3 6 . 8} \pm \mathbf{8 . 3}$ \\
\hline \multicolumn{3}{|c|}{} \\
\hline \multicolumn{2}{|c|}{ 2nd law at 298 K } & $\mathbf{1 7 3 . 3} \pm \mathbf{2 0 . 9} * *$ \\
\hline
\end{tabular}

*Temperatures are extracted from Norman et al [23] figures.

**Uncertainty listed according to Norman et al. [23].

Influence of a decrease of the $\mathrm{RuO}(\mathrm{g})$ and $\mathrm{RuO}_{2}(\mathrm{~g})$ measured partial pressures compared to equilibrium pressures on the $3^{\text {rd }}$ law enthalpies is evaluated as follow:

$$
\begin{gathered}
\Delta_{r} H^{\circ}(298 K)=-R T \ln K_{p}(T)+T \cdot \Delta_{r} F e f^{\circ}(T) \text { for equilibrium } \\
\Delta_{r} H^{*}(298 K)=-R T \ln K^{*}(T)+T \cdot \Delta_{r} F e f^{\circ}(T) \text { as measured }
\end{gathered}
$$

and for the same free energy function value,

$$
\begin{aligned}
\Delta_{r} H^{*}(298 K) & =\Delta_{r} H^{\circ}(T 298 K)+R T \ln \frac{K^{*}(T)}{K_{p}(T)} \\
& =\Delta_{r} H^{\circ}(298 K)+R T \ln \frac{\left.p_{R u O_{2}} \text { (meas. }\right)}{p_{R u o_{2}(\text { eq. })}}
\end{aligned}
$$

For a pressure ratio $\approx 0.1$ and a mean temperature of measurements $=2000 \mathrm{~K}$,

$$
\Delta_{r} H^{*}(298 K)=\Delta_{r} H^{\circ}(298 K)+38 / \mathrm{kJ} \text {. }
$$

Note that the effect is reverse for oxygen pressures when a condensation coefficient occurs.

\section{References}

[1] S. Gossé, S. Bordier, C. Guéneau, E. Brackx, R. Domenger, J. Rogez, Thermodynamic assessment of the rhodium-ruthenium-oxygen (Rh-Ru-O) system J. Nucl. Mat. , 500 (2018) 252-264.

[2] C. Chatillon, I. Nuta, F.-Z. Roki, E. Fischer, Chemical Thermodynamics of $\mathrm{RuO}_{2}(\mathrm{~s})$, J. Nucl. Mat. , 509 (2018) 742-751.

[3] A.B. Nikol'skii, Saturated Vapour Pressure of Ruthenium Tetroxide Over Aqueous Solutions, Russ. J. Inorg. Chem. (Engl. Transl.), 9 (1964) 1356-1360.

[4] E.H.P. Cordfunke, R.J.M. Konings, Thermochemical data for reactor materials and fission products, North-Holland Elsevier Science Publisher B. V., Amsterdam, 1990.

[5] H.F. Hameka, J.O. Jensen, J.G. Kay, C.M. Rosenthal, G.L. Zimmerman, Theoretical Prediction of Geometries and Vibrational Infrared Spectra of Ruthenium Oxide Molecules, J. Mol. Spectrosc., 150 (1991) 218-221. 
[6] P.E.M. Siegbahn, Binding in Second-Row Transition Metal Dioxides, Trioxides, Tetraoxides, Peroxides, and Superoxides, J. Phys. Chem., 97 (1993) 9096-9102.

[7] F. Miradji, S. Souvi, L. Cantrel, F. Louis, V. Vallet, Thermodynamic Properties of Gaseous Ruthenium Species, J. Phys. Chem. A, 119 (2015) 4961-4971.

[8] M. Zhou, A. Citra, B. Liang, L. Andrews, Infrared Spectra and Density Functional Calculations of $\mathrm{MO}_{2}$, $\mathrm{MO}_{3},\left(\mathrm{O}_{2}\right) \mathrm{MO}_{2}, \mathrm{MO}_{4}, \mathrm{MO}_{2}{ }^{-}(\mathrm{M}=\mathrm{Re}, \mathrm{Ru}, \mathrm{Os})$ and $\mathrm{ReO}_{3}{ }^{-}, \mathrm{ReO}_{4}{ }^{-}$, in solid Neon and Argon, J. Phys. Chem. A, 104 (2000) 3457-3465.

[9] M. Krauss, W.J. Stevens, Electronic Structure of FeO and RuO, J, Chem. Phys., 82 (1985) 5584-5596.

[10] L. Schäfer, H. Seip, Studies on the Failure of the First Born Approximation in Electron Diffraction: VI. Ruthenium Tetroxide, Acta Chem. Scand. , 21 (1967) 737-744.

[11] M. Pley, M.S. Wickleder, Two crystalline modifications of RuO4, J.Solid State Chem., 178 (2005) 3206-3209.

[12] R. Scullman, B. Thelin, The emission spectrum of RuO between 5000 and $6800 \AA$, J. Molecular Spectro., 56 (1975) 64-75.

[13] D.W. Green, J.G. Kay, G.L. Zimmerman, B.A. Balko, Infrared Spectrum of Ruthenium Tetroxide Isotopomers in an Argon Matrix, J. Mol. Spectrosc., 138 (1989) 62-68.

[14] H. Braune, K.W. Stute, Electronenbeugungsversuche an $\mathrm{OsO}_{4}$ und $\mathrm{RuO}_{4}$, Angew. Chem. , 51 (1938) 528.

[15] R.S. McDowell, L.B. Asprey, L.C. Hoskins, Vibrational Spectrum and Force Field of Ruthenium Tetroxide, J. Chem. Phys., 56 (1972) 5712-5721.

[16] J.G. Kay, D.W. Greene, K. Duca, Identification and Structures of Matrix-Isolated Ruthenium Oxide Molecules from Infrared Spectra, J. Mol. Spectrosc., 138 (1989) 49-61.

[17] R.E. Dodd, Infra-red spectra of ruthenium and osmium tetroxides, Trans. Far. Soc. (London), 55 (1959) 1480-1483.

[18] M.H. Ortner, Infrared spectrum and thermodynamic properties of ruthenium tetroxide, J. Chem. Phys., 34 (1961) 556-558.

[19] F. Königer, A. Müller, Molecular Constants of SiF4, GeF4, and RuO4 . An Improvement of the Analysis of the IR-band Contours of v3 (F2) by Low Temperature Measurements and by Using Isotopically Pure Compounds, J. Mol. Spectrosc., 65 (1977) 339-344.

[20] V. Raziunas, G. Macur, S. Katz, Emission Spectrum and Thermodynamic Properties of Ruthenium Monoxide, J. Chem. Phys., 43 (1965) 1010-1015.

[21] A.G. Gaydon, Dissociation Energies and Spectra of Diatomic Molecules, 3rd ed., Chapman \& Hall LTD, London, 1968.

[22] K.P. Huber, G. Herzberg, Molecular Spectra and Molecular Structure IV. Constants of Diatomic Molecules, Van Nostrand Reinhold Company, N.Y. , 1979.

[23] J. Norman, H. Staley, W. Bell, Mass Spectrometric Study of the Noble Metal Oxides, Adv. Chem. Ser. ACS, 72 (1968) 101-114.

[24] H. Schäfer, W. Gerhardt, A. Tebben, Gasförmige Rutheniumoxyde bei hoher Temperatur, Angew. Chem., 73 (1961) 27-27.

[25] H. Schäfer, G. Schneidereit, W. Gerhardt, Zur Chemie der Platinmetalle. RuO2 Chemischer Transport, Eigenschaften, thermischer Zerfall, Z. Anorg. Allg. Chem., 319 (1963) 327-336.

[26] H. Schäfer, A. Tebben, W. Gerhardt, Zur Chemie der Platinmetalle. V Gleichgewichte mit Ru (f) 5 $\mathrm{RuO}_{2}$ (f) $5 \mathrm{RuO}_{3}$ (g) und $\mathrm{RuO}_{4}$ (g), Z. Anorg. Allg. Chem., 321 (1963) 41-55.

[27] W.E. Bell, M. Tagami, HIGH-TEMPERATURE CHEMISTRY OF THE RUTHENIUM-OXYGEN SYSTEM1, The Journal of Physical Chemistry, 67 (1963) 2432-2436.

[28] B.D. Penman, R.R. Hammer, The Ruthenium dioxide- oxygen- Ruthenium tetroxide equilibrium, Idaho Nuclear Corporation, Idaho Falls, Idaho, 1968, pp. rep. IN-1013 1015 pp. 
[29] V.K. Tagirov, D.M. Chizhikov, E.K. Kazenas, L.K. Shubochkin, Study of thermal dissociation of ruthenium dioxide and rhodium sesquioxide, Russ. J. Inorg. Chem., 20 (1975) 1133-1135.

[30] J.W. Otvos, D.P. Stevenson, Cross-sections of Molecules for lonization by Electrons, J. Am. Chem. Soc., 78 (1956) 546-551.

[31] M. Chase, NIST-JANAF thermochemical tables, 4th ed., American Chemical Society (Washington, D.C. and Woodbury, N.Y.) 1998.

[32] SGPS(SGPSBase.tdb), SGTE Pure substances database (v13.1, revised 2019) in Factsage 8.0 software

[33] TDNucl(TDnucl.tdb), The NUCLEA-15 database (revised 2019) in Factsage 8.0 software by IRSN (France)

[34] L.V. Gurvich, I.V. Veyts, C.B. Alcock, Thermodynamic Properties of Individual Substances, Hemisphere Publishing Corporation London 1989.

[35] J.G. Dillard, R.W. Kiser, Ionization and Dissociation of Ruthenium and Osmium Tetroxides1, The Journal of Physical Chemistry, 69 (1965) 3893-3897.

[36] G.M. Pound, Selected Values of Evaporation Coefficients for Simple Substances, J; Phys. Chem. Ref. Data, 1 (1972) 135-146.

[37] J. Drowart, C. Chatillon, J. Hastie, D. Bonnell, High Temperature Mass Spectrometry: Instrumental Techniques, Ionization Cross-Sections, Pressure Measurements and Thermodynamic Data, Pure Appl. Chem., 77 (2005) 683-737.

[38] R. Hultgren, P.D. Desai, D.T. Hawkins, M. Gleiser, K.K. Kelley, D.D. Wagman, Selected Values of the Thermodynamic Properties of the Elements, American Society for Metals, Metals Park, Ohio 44073, 1973.

[39] K. Motzfeldt, The thermal decomposition of sodium carbonate by the effusion method, J. phys. chem., 59 (1955) 139-147.

[40] M. Heyrman, C. Chatillon, Evaporation/Condensation coefficients as determined by the multiple Knudsen cell method, J. phys. chem. solids, 66 (2005) 494-497. 